Cover: Photograph of Detroit Dam taken on July 12, 2011, by Matthew Sholtis, U.S. Geological Survey. Inset: Photograph of the tailrace of Detroit Dam taken on July 9, 2011, by Scott Evans, U.S. Geological Survey. 


\section{Behavior, Passage, and Downstream Migration of Juvenile Chinook Salmon from Detroit Reservoir to Portland, Oregon, 2014-15}

By Tobias J. Kock, John W. Beeman, Amy C. Hansen, Hal C. Hansel, Gabriel S. Hansen, Tyson W. Hatton, Eric E. Kofoot, Matthew D. Sholtis, and Jamie M. Sprando

Prepared in cooperation with the U.S. Army Corps of Engineers

Open-File Report 2015-1220

U.S. Department of the Interior

U.S. Geological Survey 


\section{U.S. Department of the Interior \\ SALLY JEWELL, Secretary}

\section{U.S. Geological Survey \\ Suzette M. Kimball, Acting Director}

U.S. Geological Survey, Reston, Virginia: 2015

For more information on the USGS—-the Federal source for science about the Earth,

its natural and living resources, natural hazards, and the environment-visit

http://www.usgs.gov/ or call 1-888-ASK-USGS (1-888-275-8747).

For an overview of USGS information products, including maps, imagery, and publications, visit http://www.usgs.gov/pubprod/.

Any use of trade, firm, or product names is for descriptive purposes only and does not imply endorsement by the U.S. Government.

Although this information product, for the most part, is in the public domain, it also may contain copyrighted materials as noted in the text. Permission to reproduce copyrighted items must be secured from the copyright owner.

Suggested citation:

Kock, T.J., Beeman, J.W., Hansen, A.C., Hansel, H.C., Hansen, G.S., Hatton, T.W., Kofoot, E.E., Sholtis, M.D., and Sprando, J.M., 2015, Behavior, passage, and downstream migration of juvenile Chinook salmon from Detroit Reservoir to Portland, Oregon, 2014-15: U.S. Geological Survey Open-File Report 2015-1220, 30 p., http://dx.doi.org/10.3133/ofr20151220. 


\section{Contents}

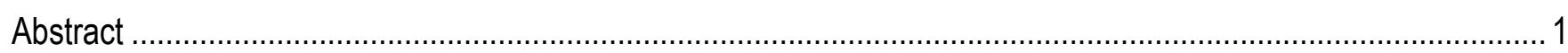

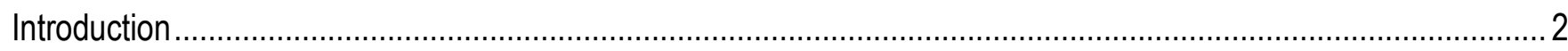

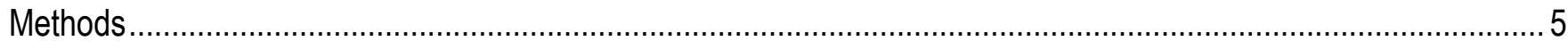

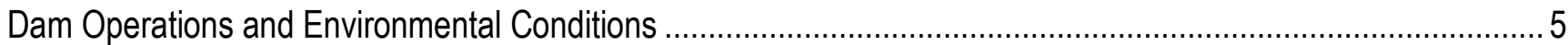

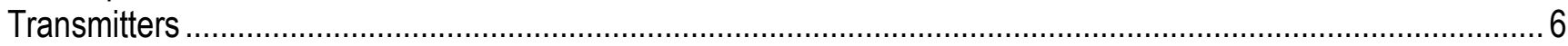

Fish Handling, Tagging, and Release ..................................................................................................

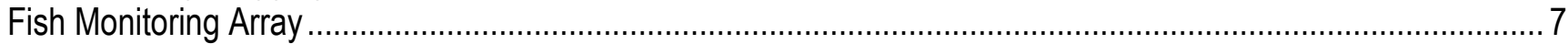

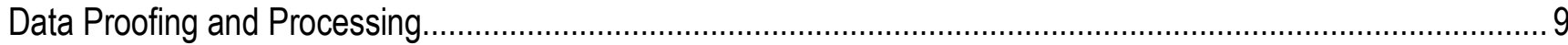

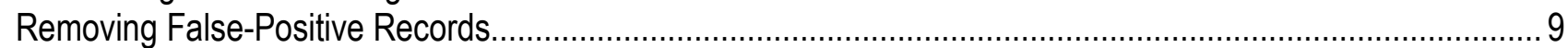

Identifying Dead Tags Prior to Release ............................................................................................. 9

Final Telemetry and Passive Integrated Transponder Tag Dataset............................................................. 10

Forebay Arrival, Passage at Detroit Dam, and Detection at Downstream Gates............................................ 10

Data Analysis Using Mark-Recapture Models ................................................................................... 11

Transmitter Life Expectancy, Transmitter Loss, and Downstream Movement of Dead Fish............................ 11

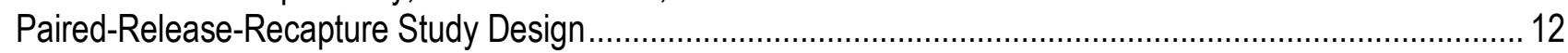

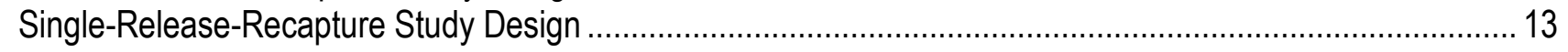

Probability of Passive-Integrated-Transponder-Tag Detection at the Bennett Dam

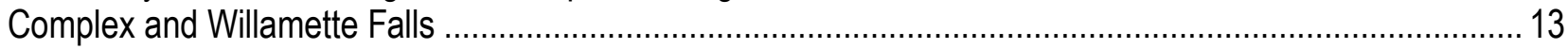

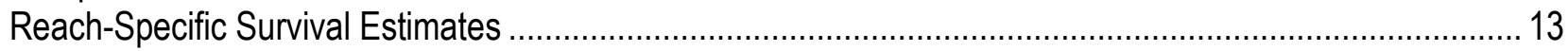

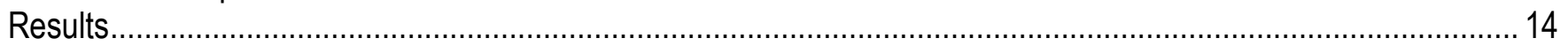

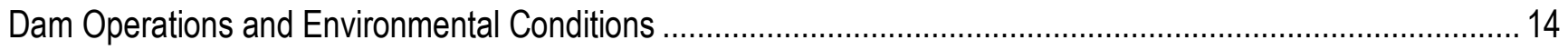

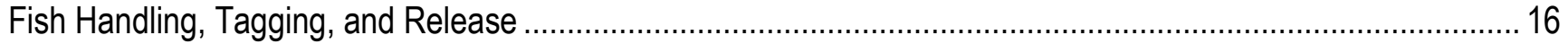

Removal of Dead Tags Prior to Release ............................................................................................. 17

Transmitter Life Expectancy, Transmitter Loss, and Downstream Movement of Dead Fish ............................... 17

Forebay Arrival, Passage at Detroit Dam, and Detection at Downstream Gates ............................................. 19

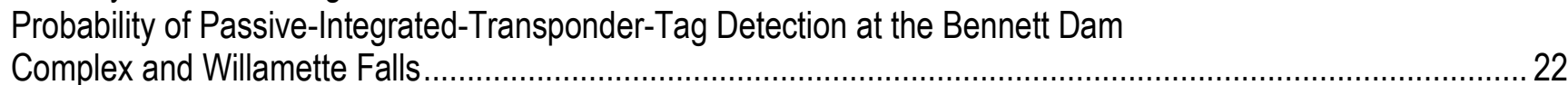

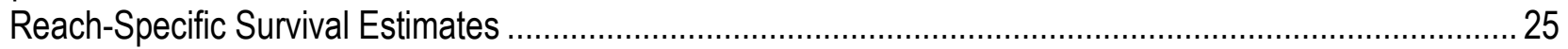

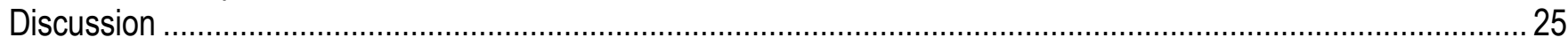

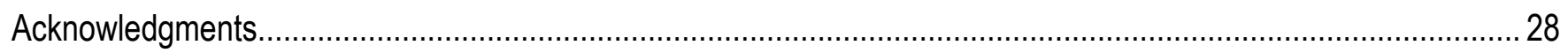

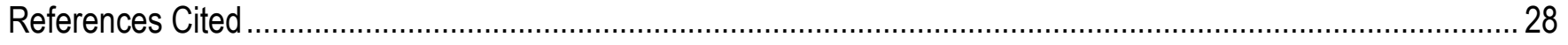




\section{Figures}

Figure 1. Schematic of the study area showing locations where acoustic telemetry equipment (circles) and Passive Integrated Transponder tag antennas (triangles) monitored tagged fish, 2014-15

Figure 2. Elevation view of the upstream side of Detroit Dam, Oregon, showing outlet structures and

elevations of full and minimum conservation pool.

Figure 3. Image showing the locations of Upper Bennett Dam, Lower Bennett Dam, and the Stayton Canal (rkm 223-220) on the North Santiam River, Oregon

Figure 4. Graphs showing daily mean operations and environmental conditions at Detroit Reservoir, Oregon, August 11-October 28, 2014, when fish were released and detected in the reservoir

Figure 5. Graph showing survival distribution function of tag life from activation to expiration for the acoustic tags used at and downstream of Detroit Reservoir, Oregon, 2014-15

Figure 6. Graph showing survival distribution function of transmitter loss from a laboratory study conducted at the Columbia River Research Laboratory, Washington, 2014-15.

Figure 7. Graph showing survival distribution of travel time from release on the North Santiam River to the forebay in Detroit Reservoir, Oregon, of acoustic-tagged Chinook salmon, 2012-14

Figure 8. Graphs showing survival distribution function of travel time from the control release near Minto Dam to the Bennett Dam complex and from the control release near Minto Dam to Willamette Falls, Oregon, of tagged Chinook salmon, 2014

Figure 9. Graphs of daily river flows in the North Santiam River, near Stayton, Oregon, and the Willamette River in Portland, Oregon, August 2014-July 2015

\section{Tables}

Table 1. Definitions of passage efficiency and effectiveness metrics.

Table 2. Summary statistics of fork length and weight of acoustic- and Passive-Integrated-Transponder-tagged hatchery Chinook salmon used in data analyses at Detroit Reservoir, Oregon, 2014

Table 3. Forebay arrival metrics and 95-percent confidence intervals for acoustic-tagged Chinook salmon at Detroit Dam, Oregon, 2012-14

Table 4. Seasonal passage metric estimates and 95-percent confidence intervals from the study of acoustictagged Chinook salmon at Detroit Dam, Oregon, 2014

Table 5. Number of treatment and control fish released and detected at acoustic telemetry and Passive Integrated Transponder (PIT) tag monitoring sites in the North Santiam and Willamette Rivers, Oregon, within the 90th percentile of the tag life of acoustic transmitters used during the study.....

Table 6. Monthly detections of acoustic+PIT-tagged Chinook salmon on Passive-Integrated-Transponder-tag antennas at the Bennett Dam complex and Willamette Falls, Oregon, 2014-15.....

Table 7. Reach-specific survival estimates from a Cormack-Jolly-Seber mark-recapture model for juvenile Chinook salmon in the North Santiam, Santiam, and Willamette Rivers, Oregon, 2014 


\section{Conversion Factors}

Inch/Pound to International System of Units

\begin{tabular}{lll}
\hline \multicolumn{1}{c}{ Multiply } & \multicolumn{1}{c}{ By } & \multicolumn{1}{c}{ To obtain } \\
\hline foot $(\mathrm{ft})$ & 0.3048 & meter $(\mathrm{m})$ \\
cubic foot per second $\left(\mathrm{ft}^{3} / \mathrm{s}\right)$ & 0.02832 & cubic meter per second $\left(\mathrm{m}^{3} / \mathrm{s}\right)$ \\
\hline
\end{tabular}

International System of Units to Inch/Pound

\begin{tabular}{lll}
\hline \multicolumn{1}{c}{ Multiply } & By & \multicolumn{1}{c}{ To obtain } \\
\hline millimeter (mm) & 0.03937 & inch (in.) \\
centimeter (cm) & 0.3937 & inch (in.) \\
meter (m) & 3.281 & foot (ft) \\
kilometer (km) & 0.6214 & mile (mi) \\
kilometer (km) & 0.5400 & mile, nautical (nmi) \\
liter (L) & 0.2642 & gallon (gal) \\
gram (g) & 0.03527 & ounce, avoirdupois (oz) \\
\hline
\end{tabular}

Temperature in degrees Celsius $\left({ }^{\circ} \mathrm{C}\right)$ may be converted to degrees Fahrenheit $\left({ }^{\circ} \mathrm{F}\right)$ as:

$$
{ }^{\circ} \mathrm{F}=\left(1.8 \times{ }^{\circ} \mathrm{C}\right)+32 \text {. }
$$

\section{Datum}

Vertical coordinate information is referenced to the National Geodetic Vertical Datum of 1929 (NGVD 29). Elevation, as used in this report, refers to distance above the vertical datum.

\section{Abbreviations}

$\begin{array}{ll}\text { CJS } & \text { Cormack Jolly Seber } \\ \text { HOR } & \text { Head of Detroit Reservoir } \\ \text { JSATS } & \text { Juvenile Salmonid Acoustic Telemetry System } \\ \text { MFH } & \text { Marion Forks Hatchery } \\ \text { MTR } & \text { Minto Dam tailrace } \\ \text { ODFW } & \text { Oregon Department of Fish and Wildlife } \\ \text { PIT } & \text { Passive Integrated Transponder } \\ \text { USACE } & \text { U.S. Army Corps of Engineers } \\ \text { USGS } & \text { U.S. Geological Survey } \\ \text { UWR } & \text { Upper Willamette River }\end{array}$


This page left intentionally blank 


\section{Behavior, Passage, and Downstream Migration of Juvenile Chinook Salmon from Detroit Reservoir to Portland, Oregon, 2014-15}

By Tobias J. Kock, John W. Beeman, Amy C. Hansen, Hal C. Hansel, Gabriel S. Hansen, Tyson W. Hatton, Eric E. Kofoot, Matthew D. Sholtis, and Jamie M. Sprando

\section{Abstract}

An evaluation was conducted to estimate dam passage survival of juvenile Chinook salmon (Oncorhynchus tshawytscha) at Detroit Dam during a period of spill. To estimate dam passage survival, we used a paired-release recapture study design and released groups of tagged fish upstream (997 fish) and downstream (625 fish) of Detroit Dam. A total of 43 fish (6.8 percent) passed Detroit Dam from the upstream release group and passage occurred through regulating outlets (54.8 percent), spill bays (31.0 percent), and turbines (14.3 percent). We do not present dam passage survival estimates from 2014 because these estimates would have been highly uncertain due to the low number of fish that passed Detroit Dam during the study. Secondary objectives were addressed using data collected from tagged fish that were released at the downstream release site.

Juvenile salmonids have multiple passage options at the Bennett Dam complex, which includes a series of dams and braided channels. A pair of Passive Integrated Transponder (PIT) monitoring arrays were installed at Upper Bennett Dam and in the Stayton Canal by the U.S. Army Corps of Engineers and the Oregon Department of Fish and Wildlife during 2014. We deployed acoustic telemetry hydrophones near these arrays to detect acoustic-tagged fish from our study and used these detections to quantify proportions of tagged fish passing through the two routes. About one-fourth (0.257) of the tagged fish that were released downstream of Big Cliff Dam were detected on the new PIT tag array while passing the Bennett Dam complex. A total of 402 acoustic-tagged fish were detected at the complex and many (248 fish; 62 percent) eventually entered the Stayton Canal. Median residence time in the canal was 6.5 hours, but 12.7 percent of the fish had extended residence times (7-37 days). Passage also was monitored at the Sullivan Project at Willamette Falls and about 40 percent (0.398) of the tagged fish passing the project were detected on the PIT tag array. 
A Cormack-Jolly-Seber mark-recapture model was developed to provide reach-specific survival estimates for juvenile Chinook salmon. A portion of the tagged population overwintered in the Willamette River Basin and outmigrated several months after release. As a result, survival estimates from the model would have been negatively biased by factors such as acoustic tag failure and tag loss. Data from laboratory studies were incorporated into the model to provide survival estimates that accounted for these factors. In the North Santiam River between Minto Dam and the Bennett Dam complex, a distance of 37.2 kilometers, survival was estimated to be 0.844 (95-percent confidence interval 0.795-0.893). The survival estimate for the 203.7 kilometer reach between the Bennett Dam complex and Portland, Oregon, was 0.279 (95-percent confidence interval 0.234-0.324), and included portions of the North Santiam, Santiam, and Willamette Rivers. The cumulative survival estimate in the 240.9 kilometer reach from the Minto Dam tailrace to Portland was 0.236 (95-percent confidence interval $0.197-0.275)$.

\section{Introduction}

The U.S. Army Corps of Engineers (USACE) operates the Willamette Valley Project (Project) in western Oregon, which is comprised of a series of dams, revetments, and hatcheries. The primary purpose of the Project is flood risk management, but it also is operated to provide hydroelectricity, irrigation water, navigation, instream flows for wildlife, and recreation. The Project includes 13 dams, about $68 \mathrm{~km}$ of revetments, and several fish hatcheries. Detroit Dam, and several other dams, are located on tributaries of the Willamette River. In 2008, the National Oceanic and Atmospheric Administration determined that the Project was jeopardizing the sustainability of anadromous fish stocks in the Willamette River Basin (National Oceanic and Atmospheric Administration, 2008). This determination has resulted in an increased need for quality data that can be used by fishery managers in the basin.

In 1953, the USACE constructed Detroit Dam on the North Santiam River, about $65 \mathrm{~km}$ east of Salem, Oregon (fig. 1). The primary purposes of the $461 \mathrm{ft}$ tall dam are flood control, power generation, navigation, and recreation. The dam has six spill bays, five regulating outlets, and two Francis turbines with a total hydraulic capacity of $5,340 \mathrm{ft}^{3} / \mathrm{s}$ and a generating capacity of 115 megawatts. The ceilings of the turbine intakes are at an elevation of 1,419 $\mathrm{ft}$ and the ceilings of the upper regulating outlet openings are at an elevation of 1,356 ft (fig. 2). The spillway ogee is at an elevation of 1,541 ft. Reservoir elevation normally ranges from 1,450 to $1,564 \mathrm{ft}$, with highest elevations in the summer and lowest elevations in the winter, for flood control and recreation purposes. Fluctuations in discharge at Detroit Dam to meet power demand are re-regulated at Big Cliff Dam, located $4.2 \mathrm{~km}$ downstream.

Detroit Dam is operated in coordination with other dams in the Project. Flood control dams within the Project are filled during summer to benefit recreation and power generation and are drawn down during autumn and winter to facilitate flood control. Detroit Dam is scheduled as the first dam in the Project to fill during spring and the last dam to be drawn down during autumn; a flood-control elevation of $1,450 \mathrm{ft}$ is normally maintained from December 1 to January 31 . Site-specific rules also govern the use of the spillway and regulating outlets and their use is dependent on forebay water elevations, so the two routes are rarely used together. Additionally, to meet the demand for electricity and instream water temperatures and flows downstream, the powerhouse, spillway, and regulating outlets are operated singly, in various combinations, or not at all, resulting in a variety of dam operating conditions. 


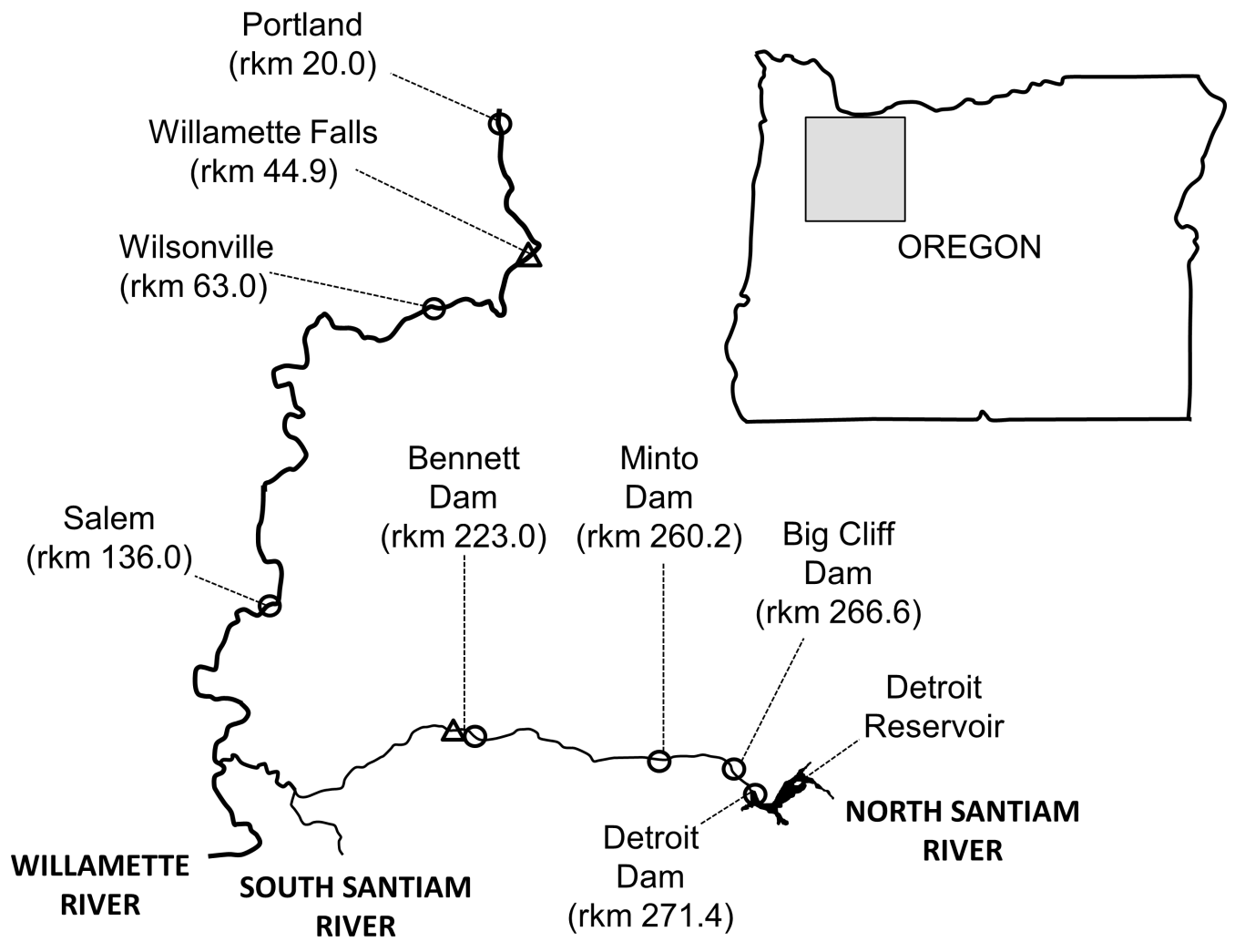

Figure 1. Schematic of the study area showing locations where acoustic telemetry equipment (circles) and Passive Integrated Transponder tag antennas (triangles) monitored tagged fish, 2014-15.

Full pool

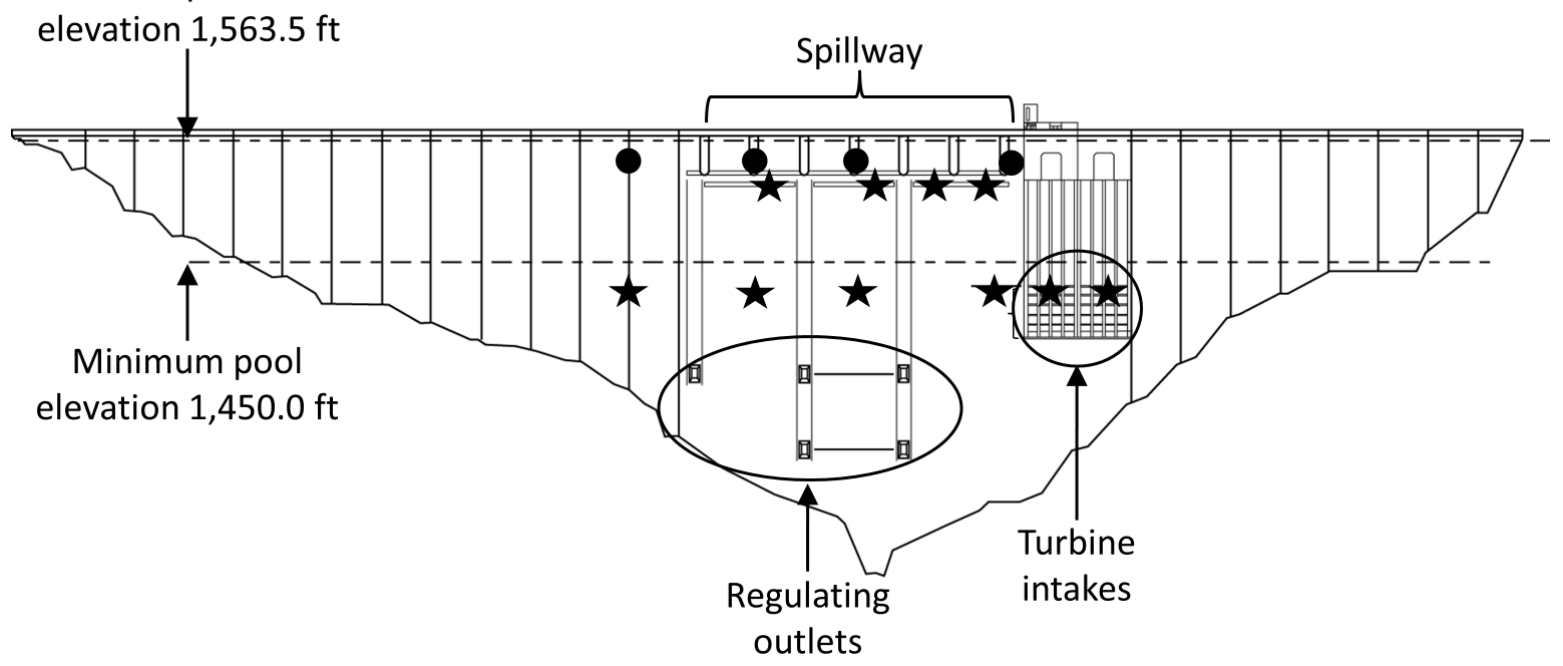

Figure 2. Elevation view of the upstream side of Detroit Dam, Oregon, showing outlet structures and elevations of full and minimum conservation pool. Also shown are the locations of cabled hydrophones on the upstream side of the dam. Stars represent hydrophones affixed to the dam face, and circles indicate hydrophones deployed from a floating platform attached to guide cables on the dam face. 
The 2008 Willamette Biological Opinion requires improvements to Project operations and structures to reduce impacts on Upper Willamette River (UWR) Chinook salmon (Oncorhynchus tshawytscha) and UWR steelhead (Oncorhynchus mykiss) (National Oceanic and Atmospheric Administration, 2008). The improvements include a requirement to mediate unseasonable water temperatures passed through the high-head dam by 2017 and to install fish passage facilities (or operational alternatives) at Detroit Dam by 2023. Among the alternatives designed to meet these mandates is a temperature control structure at the dam that also enables downstream fish passage. However, in the interim period, downstream passage of juvenile anadromous salmonids is to be achieved with the current configuration of the dam. In 2007, the USACE initiated operations at Detroit Dam to simultaneously pass water through the spillway and powerhouse (hereinafter temperaturecontrol spill). This operation results in a mixing of warmer surface water (passed through the spillway) with cooler deep water (passed through the powerhouse) to yield water temperatures downstream of Detroit Dam that are suitable for salmonids during summer and early autumn. Temperature-control spill operations are terminated in late-summer/early-autumn when the forebay water elevation falls below the spillway ogee elevation. Temperature-control spill operations are designed to improve water temperature conditions downstream of Detroit Dam, but there is also evidence to suggest that these operations improve dam passage conditions for juvenile salmon that out-migrate from Detroit Reservoir.

Several studies have shown that juvenile salmon passage rates are highest at Detroit Dam when the spillway is operating and spillway passage survival appears to be high as well. Juvenile salmonid passage was evaluated at Detroit Dam during 2012-14 when juvenile Chinook salmon and juvenile steelhead were monitored using acoustic telemetry (Beeman and others, 2014; 2015). These studies showed that juvenile salmonid passage was highest when spillway passage routes were available, and the authors concluded that "the spring-dominated seasonal passage at Detroit Dam is largely owing to the operation of the seasonally available spillway during spring and summer." Results from another study by the Oregon Department of Fish and Wildlife (ODFW) support the idea that spillway passage is important for juvenile salmonids at Detroit Dam. In August 2012, two groups of PIT-tagged Chinook salmon (12,500 fish per group) were released in the North Santiam River (T.A. Friesen and M.A. Johnson, ODFW, written commun., February 2013). The first group was released at the head of Detroit Reservoir (HOR), and the second group was released into the Minto Dam tailrace (MTR), $10 \mathrm{rkm}$ downstream of Detroit Dam. Migration patterns for each group were compared using PIT tag detections at the Sullivan Hydroelectric Plant at Willamette Falls, Oregon City, Oregon, hereinafter called Willamette Falls. Willamette Falls is located in the mainstem Willamette River, $252 \mathrm{rkm}$ downstream of Detroit Dam (fig. 1). The ratio of total detections between the two groups at Willamette Falls was 1.17MTR:1.00HOR, which suggests that downstream movements and survival rates were fairly similar between the two groups, although the HOR group had to pass through two more reservoirs and dams (including Detroit Dam) than the MTR group. The detections at Willamette Falls occurred primarily during September and October 2012, which means that HOR fish were mostly passing Detroit Dam when temperature-control spill operations occurred (spill was terminated on September 23, 2012). Finally, Normandeau and Associates, Inc. (2010) evaluated passage route mortality at Detroit Dam using balloon-tagged juvenile Chinook salmon. They found that direct survival varied by passage route and dam operation but reported that 48-h post-passage survival ranged from 72 to 94 percent through the regulating outlets, from 64 to 80 percent through the spillway, and was 54 percent through the turbines. Given these findings, the USACE identified a need to acquire additional information on dam passage survival of juvenile salmonids at Detroit Dam during periods of temperature-control spill. 
This report summarizes an evaluation of dam passage survival at Detroit Dam that was conducted during 2014-15. The evaluation was developed to duplicate the 2012 ODFW study and included two groups of PIT-tagged fish (10,000 fish per group) with HOR and MTR release sites. A subset of fish from each release group were also tagged with an acoustic transmitter, which allowed us to maintain high detection probabilities of study fish at numerous locations throughout the North Santiam and Willamette Rivers. The study was designed to estimate dam-passage survival at Detroit Dam to specifically evaluate temperature-control spill operations, but we anticipated that downstream detections of tagged fish would also allow us to address secondary objectives. Secondary objectives included collecting data at two locations downstream of Detroit Dam-(1) the Bennett Dam complex; and (2) Willamette Falls. The North Santiam River is braided at the Bennett Dam complex and water is withdrawn from the river through the Stayton Canal, so multiple fish passage options exist for downstream migrants. The USACE funded the deployment of two new PIT tag monitoring arrays at the Bennett Dam complex during 2014. We monitored this area for passage of acoustic-tagged fish to help determine which routes were used by migrants and to assess the performance of the PIT tag monitoring arrays (Street and Faber, 2015). Willamette Falls is an important monitoring site in the Willamette River Basin because it is the downstream-most location where year-round PIT tag monitoring occurs in the mainstem Willamette River. As a result, PIT tag detections at Willamette Falls are often used in calculations that estimate outmigration survival for juvenile salmonid populations within the basin. These calculations require information about the probability of tagged fish passing through, and being detected in, monitored passage routes at the dam. However, little information was available regarding PIT tag detection probabilities at Willamette Falls. Thus, our study plan included an assessment of the detection probability of PIT-tagged fish at Willamette Falls. Finally, a series of acoustic monitoring arrays were located throughout the North Santiam and Willamette Rivers, and detection records from these sites were analyzed to estimate reach-specific survival probabilities during the study period. This report contains results for Chinook salmon that were tagged with acoustic transmitters and PIT tags and monitored during August 2014-June 2015.

\section{Methods}

\section{Dam Operations and Environmental Conditions}

Powerhouse discharge, regulating outlet discharge, spillway discharge, forebay elevation, and water temperature data from 2014 were summarized to document environmental conditions during the study period. Hourly operation data from Detroit Dam were obtained from the USACE, which included powerhouse discharge, regulating outlet discharge, regulating outlet openings, spillway discharge, spill gate openings, and forebay elevation data. Hourly data records were averaged to create daily operation records that were used for analysis or presented in plots in this report. Water elevation data are presented in feet and discharge data are presented in cubic feet per second in accordance with local convention. Hourly temperature data were obtained from the USACE Website, http://www.nwdwc.usace.army.mil/ftppub/water_quality/tempstrings. Diel periods were assigned using U.S. Naval civil twilight records, which were obtained at http://www.usno.navy.mil/USNO/astronomical-

applications/astronomical-applications. River flow data were downloaded for USGS streamgages in the North Santiam River (14183000) and Willamette River (14211720). Data were obtained at http://waterdata.usgs.gov/usa/nwis/uv?site_no $=14183000$ and http://waterdata.usgs.gov/usa/nwis/uv?site_no $=14211720$. 


\section{Transmitters}

We surgically implanted an acoustic transmitter into each fish. We used the juvenile salmon acoustic telemetry system (JSATS; McMichael and others, 2010). The model SS3300 JSATS tag was manufactured by Advanced Telemetry Systems (ATS; Isanti, Minnesota) and had a mean mass in air of $0.31 \mathrm{~g}$ (range $0.27-0.32$ ). The dimensions were $10.71 \mathrm{~mm}$ long $\times 5.20 \mathrm{~mm}$ wide $\times 3.07 \mathrm{~mm}$ deep. Expected transmitter life at the nominal pulse rate interval (PRI) of 15 seconds was 90 days. A 12.5mm-long full-duplex PIT tag (model SST, Biomark, Boise, Idaho) weighing $0.10 \mathrm{~g}$ was inserted into fish in June as part of the ODFW paired-release study.

\section{Fish Handling, Tagging, and Release}

The fish studied were hatchery subyearling Chinook salmon (hereinafter Chinook salmon) that were reared, tagged, and held at the Marion Forks Hatchery (MFH) in Idanha, Oregon, prior to release. Our study was developed in collaboration with ODFW, who were evaluating juvenile outmigration and adult return patterns of PIT-tagged Chinook salmon released upstream and downstream of several large reservoirs in the Willamette River Basin. The ODFW study was a multi-year effort and sample sizes for individual release groups generally range from 10,000 to 30,000 fish per group. For our study, two groups of Chinook salmon (10,000 fish each) were reared in separate concrete ponds at the MFH during 2014. The circular rearing ponds were $7.3 \mathrm{~m}$ in diameter and $0.65 \mathrm{~m}$ in depth and held $27,750 \mathrm{~L}$ of flowthrough river water. Fish in the first pond comprised the treatment group for our study and were destined for release at the HOR. Fish in the second pond comprised the control group and were destined for release into the MTR. All Chinook salmon in our study were PIT-tagged and a subset of the PITtagged fish (approximately 10 percent) were also tagged with an acoustic transmitter. PIT-tagging occurred during June 24-29, 2014, and acoustic tagging occurred during August 4-9, 2014. The ODFW was responsible for PIT-tagging, and the U.S. Geological Survey (USGS) was responsible for acoustic tagging.

Acoustic transmitters were surgically implanted into study fish using the acoustic tagging protocol that was developed by the Surgical Protocols Steering Committee (Axel and others, 2011). Fish were considered suitable for tagging if they were greater than or equal to $95 \mathrm{~mm}$ long; free of major injuries; had no external signs of gas bubble trauma, major fin damage or fungus; were less than 20 percent descaled; and had no visible signs of deformities or disease. Fish size data collected during the PIT-tagging process suggested that many of the Chinook salmon in the treatment and control ponds would not be large enough for tagging by early August 2014. To increase the likelihood of tagging fish in early August, MFH staff increased feed rates during July 2014 to increase fish growth. Fish were sorted on July 22, 2014, to obtain fish that were large enough for acoustic tagging. During this process, fish were removed from the ponds, anesthetized with buffered tricane methanesulfonate (MS-222, Argent Chemical Laboratories, Redmond, Washington) and transferred into an indoor treatment or control trough if they were greater than or equal to $90 \mathrm{~mm}$ long. Each indoor trough was 4.9-m-long, 1.0-m-wide, and 0.81-m-deep, and each one held 3,936 L of flow-through river water. Fish that failed to meet the size minimum were returned to their original outdoor pond. A total of 1,317 Chinook salmon were retained in the treatment trough and 1,518 Chinook salmon were retained in the control trough. The fish were held in the indoor troughs for 11-17 days prior to tagging. The tagging protocol indicates that fish should be held, without feeding, for 18-30 hours prior to tagging. To accomplish this, groups of fish (approximately 300 fish per day) were transferred daily (beginning on August 3 ) from each indoor trough into one of two pre-tag holding containers (246 L with flow-through river water), where they were held overnight for tagging the following day. At the time of tagging, fish were anesthetized in a MS-222 bath (80-90 mg/L). Weight and fork length data for each fish were collected prior to tag 
implantation. All weighing, measuring, and containment equipment was treated with a $0.25 \mathrm{~mL} / \mathrm{L}$ concentration of Stress Coat ${ }^{\circledR}$ (Aquarium Pharmaceuticals, Inc., Chalfont, Pennsylvania) to reduce handling-related stress (via electrolyte loss). Fish were placed into a 19-L perforated bucket filled with 7 L of river water immediately after surgery. Dissolved oxygen concentrations were maintained between 80 and 110 percent saturation during recovery. The maximum density in a recovery bucket was less than $13.5 \mathrm{~g} / \mathrm{L}$ and no more than four tagged fish were held in a single bucket. Fish in the recovery buckets were observed periodically during the first 10 minutes after surgery to ensure they recovered from anesthesia. After the 10-minute recovery period, tagged fish were transferred from the recovery buckets into the outdoor treatment or control pond. A subsample (25 fish) of the acoustic-tagged control fish were placed into a third outdoor pond that was identical to the treatment and control ponds. These fish were euthanized at the time of release of the control group and were released with the rest of the control fish in the MTR to test one of the survival model assumptions (see section, "Transmitter Life, Transmitter Loss, and Downstream Movement of Dead Fish"). All fish releases were made by ODFW using a fish transport truck that held 3,785 L of water. Fish were released from the truck into the river through a 38.6-cm-diameter hose.

\section{Fish Monitoring Array}

We used autonomous (non-cabled) and cabled JSATS hydrophones to monitor acoustic-tagged fish during the study period. A 2011 assessment of JSATS hydrophone detection range in Cougar Reservoir, Oregon, showed that 82 percent of the expected number of transmissions were successfully logged at a range of $105 \mathrm{~m}$, whereas only 10 percent of the transmissions were successfully logged at $180 \mathrm{~m}$ (U.S. Geological Survey, unpub. data, 2011). Based on these data, autonomous hydrophones were deployed no more than $100 \mathrm{~m}$ from shorelines and no more than $200 \mathrm{~m}$ from the nearest hydrophone (perpendicular to river flow) to achieve a high detection probability.

Hydrophone arrays were operated immediately upstream of the Detroit Dam forebay and on Detroit Dam to detect tagged fish as they approached the dam. Five hydrophones were located upstream of the Detroit Dam forebay (rkm 271) and were deployed using methods similar to those described by Titzler and others (2010), except that burlap bags of sand were used as anchors. Fourteen hydrophones were deployed on the face of Detroit Dam (fig. 2) using four JSATS cabled systems that were linked to each other via a common clock. Each system was comprised of two or four hydrophones and a computer that received a system time from a global positioning system (GPS) receiver (Meinberg GPS 170PCI, Meinberg Funkuhren GmbH \& Co. KG, Bad Pymont, Germany). The cabled hydrophone system is described by Weiland and others (2009). Cabled hydrophones were installed at several elevations on the face of Detroit Dam to provide detection coverage as forebay water levels changed. For example, four hydrophones were located just below the crest of the spillway (fig. 2) and were operational only when forebay water levels were higher than 1,531 ft. Detection ranges of dam-mounted hydrophones were assumed to be similar to autonomous hydrophones in the forebay so fish detections were likely when fish were within $100 \mathrm{~m}$ of the dam.

A series of acoustic telemetry and PIT tag monitoring sites were located downstream of Detroit Dam to detect fish that moved through the North Santiam, Santiam, and lower Willamette Rivers (fig. 1). A total of 25 autonomous hydrophones were located at six monitoring sites downstream of Detroit Dam: 2 each at Big Cliff and Minto Dams, 3 at the Bennett Dam Complex (fig. 3), and 6 each in Salem, Wilsonville, and Portland. Hydrophones located downstream of Detroit Dam were deployed using methods described by Beeman and Adams (2015). PIT tag monitoring sites were present at two locations in the Bennett Dam complex (Upper Bennett Dam and the Stayton Canal) and at Willamette Falls. 


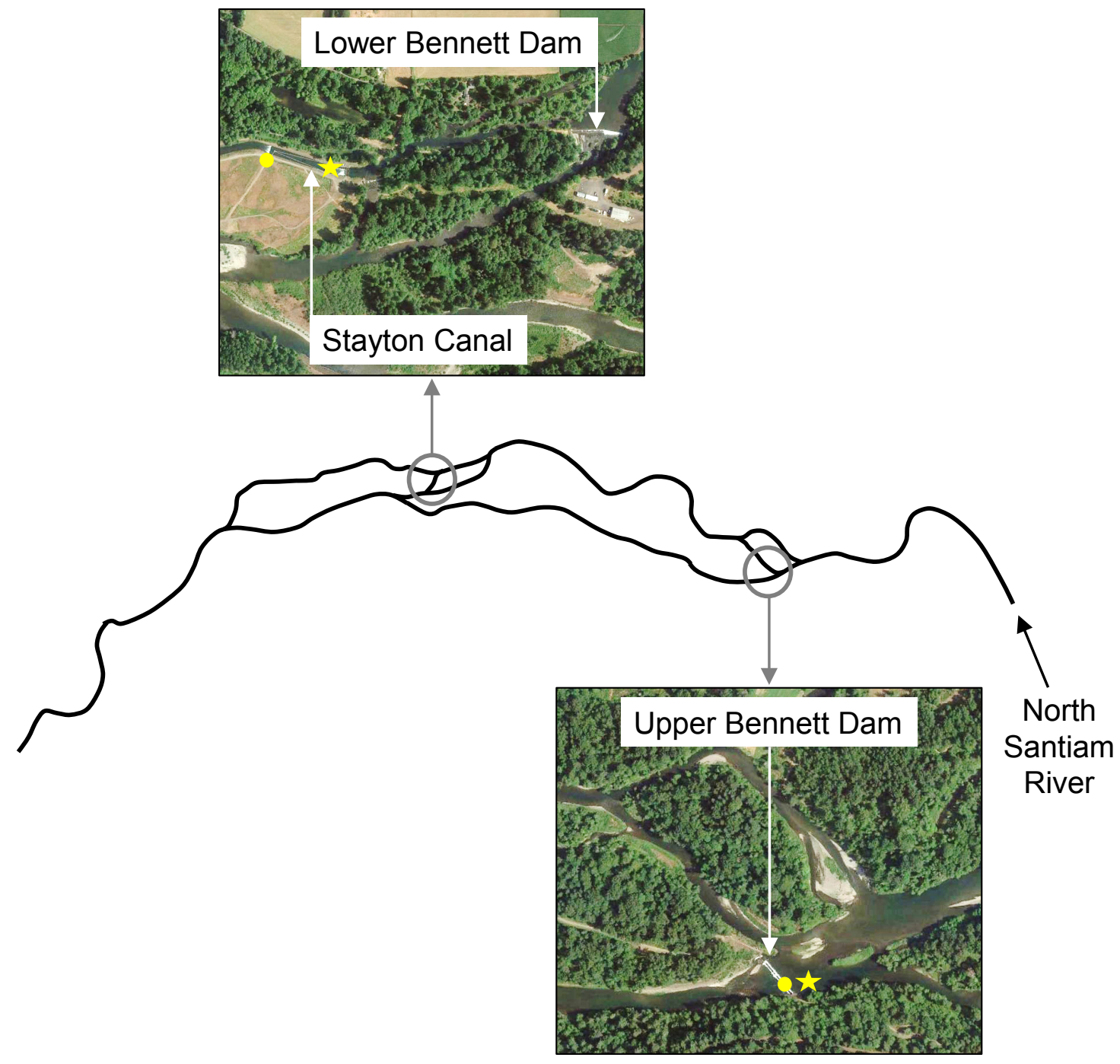

Figure 3. Image showing the locations of Upper Bennett Dam, Lower Bennett Dam, and the Stayton Canal ( $\mathrm{rkm}$ 223-220) on the North Santiam River, Oregon. Embedded photos show the locations of PIT tag antennas (yellow circles) and acoustic hydrophones (yellow stars). Photo source: "Bennett Dam." 44047'32.64" N 122045'34.25" W. GOOGLE EARTH. July 14, 2014. January 28, 2015. 
The USACE funded the installation of two new PIT tag monitoring sites that were deployed at the Bennett Dam Complex prior to our study in 2014. Because we expected to have substantial numbers of acoustic+PIT-tagged fish passing through the Bennett Dam complex, acoustic telemetry equipment was installed near the PIT tag monitoring sites to help assess their performance and to quantify proportions of fish using various routes. At Upper Bennett Dam, PIT tag antennas were located inside the adult fish ladder, located on the southern end of the dam, and along the upstream side of the spillway on the dam. One autonomous acoustic hydrophone was deployed upstream of the entrance to the adult fish ladder to detect tagged fish as they approached Upper Bennett Dam (fig. 3). In the Stayton Canal, PIT tag antennas were deployed at the upstream end of the pipe that returns fish to the North Santiam River. Two autonomous hydrophones were deployed just upstream of the PIT tag antennas in the Stayton Canal to detect fish that entered the canal. Additional descriptions of PIT tag sites at the Bennett Dam Complex and system performance during 2014 can be found in Street and Faber (2015).

At Willamette Falls, PIT tag antennas are located inside the two juvenile fish bypasses and in the adult fish ladders. However, fish can still pass through unmonitored routes (the spillway, for example) and testing results suggested that detection probabilities of PIT tag antennas in the juvenile fish bypasses are highly variable (Nick Ackerman, Portland General Electric, written commun., January 2015). We did not deploy acoustic hydrophones at Willamette Falls because our Wilsonville and Portland sites have historically had very high detection probabilities and are located within $20 \mathrm{rkm}$ of the dam. Given these factors, we expected to detect almost all acoustic-tagged fish that migrated through the Wilsonville-to-Portland reach, which would provide ideal conditions for determining the proportion of PIT-tagged fish that were detected at Willamette Falls.

\section{Data Proofing and Processing}

\section{Removing False-Positive Records}

Acoustic telemetry data records were processed to remove false-positive detection events prior to analyzing fish movement data. False-positive records indicate detection of a transmitter when the transmitter was not present, and are common in most active telemetry systems (Beeman and Perry, 2012). We used a procedure developed by the Pacific Northwest National Laboratory (Mark Weiland, Pacific Northwest National Laboratory, written commun., June 17, 2010) to remove false-positive records. This procedure removed records if (1) the detection record was from a tag code that was not released during the study; (2) the record matched criteria that indicated the detection likely resulted from reflections of valid tag signals (multipath); (3) the detection record did not match a multiple of the tag pulse interval; or (4) the record was not followed by at least three valid records from the autonomous hydrophone or five valid records from a cabled hydrophone system (McMichael and others, 2010). Additionally, detection records that were collected on the cabled hydrophone systems were retained only if each detection event was simultaneously received on at least two hydrophones in the detection array.

\section{Identifying Dead Tags Prior to Release}

Autonomous hydrophones monitored holding ponds at MFH to verify that transmitters were functioning properly prior to fish releases. Detection records from the holding ponds were analyzed during the 64-hour period that occurred immediately before each fish release. Tags that were detected during the 64-hour pre-release period were considered to be functioning properly. Tags that were not detected during the 64-hour pre-release period were considered non-functional, and were removed from the final detection dataset. 


\section{Final Telemetry and Passive Integrated Transponder Tag Dataset}

A final dataset was created by merging telemetry detection records with PIT-tag detection records. The final telemetry dataset was developed by removing false-positive records and dead tags from the preliminary telemetry dataset. A final PIT-tag dataset was created by querying the Columbia Basin PIT Tag Information System (PTAGIS) Website (www.ptagis.org) for detection events of tagged fish at PIT tag sites in the North Santiam, Willamette, and Columbia Rivers. These monitoring sites included antennas at the Bennett Dam complex, Willamette Falls, and at various tributary and nearshore monitoring arrays located in the lower Willamette and Columbia Rivers. The tagging and release data, final telemetry dataset, and PIT tag detection records were then merged and sorted chronologically for each fish in the study. The final dataset was then queried to summarize fish detections at specific sites in the study area. These summaries were used to describe movement patterns of tagged fish and to create capture histories that were analyzed using mark-recapture survival models.

\section{Forebay Arrival, Passage at Detroit Dam, and Detection at Downstream Gates}

The final dataset was analyzed to determine when fish arrived at Detroit Dam to assign route-ofpassage at the dam and to determine when fish passed monitoring sites downstream of the dam. Arrival in the Detroit Dam forebay was assigned at the first date and time when tagged fish were detected on hydrophones located $1 \mathrm{rkm}$ upstream of Detroit Dam. Route of passage at Detroit Dam was assigned using the physical location of the hydrophone that received the first detection of the last detection for each tag, prior to passage. Spillway passage was assigned when tagged fish were last detected on hydrophones located near the spillway, regulating outlet passage was assigned when tagged fish were last detected on hydrophones located near the regulating outlet, and powerhouse passage was assigned when fish were last detected on hydrophones located near the powerhouse. Previous studies included metrics for fish movement through Detroit Reservoir and fish passage at Detroit Dam (Beeman and others, 2014; 2015). The calculation of these metrics were included in our analysis, where possible, to provide annual comparisons between studies. We also calculated a new metric, forebay arrival efficiency, which is the number of fish detected in the forebay of Detroit Dam divided by the number of fish released in the tributary upstream of Detroit Reservoir (table 1). Forebay arrival efficiencies from autumn releases during 2012-14 were compared using a chi-square test of independence with a Bonferroni correction to the P-value. Detection events downstream of Detroit Dam were summarized to determine when tagged fish arrived at a site, using the date and time of the first detection event at that site. Similarly, the date and time of the last detection at a given site was used to determine when a tagged fish left that site. Residence time at a given site was calculated as the elapsed time between the first and last detection events at that site. Travel time between sites was calculated as the elapsed time between the last detection event at the upstream site and the first detection event at the downstream site. 
Table 1. Definitions of passage efficiency and effectiveness metrics.

[RO, regulating outlet; Number, number of tagged fish]

\begin{tabular}{lcl}
\hline \multicolumn{1}{c}{ Metric } & Acronym & Definition \\
\hline Forebay arrival efficiency & FAE & Number detected at forebay divided by number released. \\
Dam passage efficiency & DPE & Number passing the dam divided by number detected at forebay. \\
Spill passage efficiency & SPE & $\begin{array}{c}\text { Number passing the spillway divided by number passing the dam with known } \\
\text { routes. }\end{array}$ \\
Turbine passage efficiency & TPE & $\begin{array}{c}\text { Number passing the turbines divided by number passing the dam with known } \\
\text { routes. }\end{array}$ \\
RO passage efficiency & ROE & $\begin{array}{c}\text { Number passing the RO divided by number passing the dam with known routes. } \\
\text { Fish passage efficiency }\end{array}$ \\
\hline
\end{tabular}

\section{Data Analysis Using Mark-Recapture Models}

\section{Transmitter Life Expectancy, Transmitter Loss, and Downstream Movement of Dead Fish}

Mark-recapture models are commonly used to analyze telemetry datasets when assessing migration survival of juvenile salmonids. These models account for detection probabilities at monitoring sites to provide unbiased estimates of migration survival as fish move between monitored areas in a given study. Mark-recapture models are associated with a series of assumptions that can be empirically assessed to minimize bias in model outputs. For example, mark-recapture models assume that live tagged fish are detectable as they move downstream and pass a given monitoring site. However, this may not be true if the transmitter inside a fish stops operating before the fish passes that site, or if the fish sheds the transmitter prior to passing. These models also assume that fish detections occur only when live fish pass downstream, but it is possible for dead fish to be detected if they are moving downstream with river flow and possess an active transmitter. Consequently, it is important to evaluate transmitter life expectancy, transmitter loss, and downstream movement of dead fish so that these factors can be accounted for during the analysis process.

To determine transmitter life expectancy (hereinafter tag life), 50 transmitters were evaluated in a laboratory setting during July-November 2014. These transmitters were randomly selected from the transmitters that were available for the field study. The tag-life study was conducted in two $1.5-\mathrm{m}-$ diameter circular tanks at the Columbia River Research Laboratory (CRRL) in Cook, Washington. Transmitters were activated on July 30 and 31,2014, and placed into one of two plastic boxes that were $82.6 \mathrm{~mm}$ wide, $279.4 \mathrm{~mm}$ long, and $31.7 \mathrm{~mm}$ deep. The plastic boxes and transmitters were then submerged in the circular tank where they remained for the duration of the study. Water temperatures in the tank were controlled to simulate average monthly water temperatures in Detroit Reservoir during August-November. Transmitter signals were monitored with an Advanced Telemetry Systems receiver (Model Trident SR5000). Data were processed in the same manner as data collected during the study period and were summarized using a Kaplan-Meier survivorship analysis (Allison, 1995). 
Transmitter loss was also empirically evaluated in a laboratory study at CRRL during 2014-15. A total of 94 fish were tagged on December 16 and 17, 2014, and evaluated through May 27, 2015. Fish size and water temperature were controlled to insure that these variables matched conditions in the field study. Fish were tagged with an acoustic transmitter and a PIT tag and held at approximately $12{ }^{\circ} \mathrm{C}$ in one of two 1.5-m diameter circular tanks at the CRRL. Fish were fed six times per day at a 1.5 (maintenance diet) or 3 percent (growth diet) feed rate. The growth diet was intended to mimic the feeding regime at MFH during summer 2014, prior to when acoustic tagging occurred. Tanks were checked each weekday during the study for shed transmitters. Tag loss was assigned to the date the tank was last checked prior to tag recovery. All fish were examined at 42 and 106 days post-tagging. On these days, fish were lightly anesthetized, measured in length and weight, and photographs were taken of the ventral and lateral sides of each fish. A random subsample of approximately 12 fish were also removed on each examination day, euthanized, and necropsied for internal examinations. In addition, at 106 days we removed and necropsied one fish that was in the process of expelling the acoustic transmitter. Tag-loss data were analyzed using a Kaplan-Meier survivorship analysis. Fish that were removed for necropsies were right-censored at the day of sampling if tag loss had not occurred.

A subsample of the control fish were euthanized and released with the rest of the live control fish to determine the rate of false positives in detections downstream (detection of dead fish with live transmitters). As previously described, 25 of the acoustic-tagged fish from the control group were randomly selected for euthanasia. These fish were held in a separate holding pond at MFH during the post-tagging holding period to facilitate the euthanasia process that occurred on the day of the control fish release. The euthanasia process began when live control fish were being loaded onto the fish transport truck. At that time, control fish were removed from their holding pond and submersed in a $7 \mathrm{~L}$ anesthetic bath of MS-222 (200 mg/L) for 30 minutes. Fish were transported to the release site during the 30-minute submersion period, so the final two steps in the euthanasia process were conducted at the release site. At the end of the 30-minute period, fish were removed from the anesthetic bath, their gill arches were severed and they were pithed with a dissecting needle. The dead control fish were then released with the live control fish.

\section{Paired-Release-Recapture Study Design}

A paired-release recapture study design (hereinafter paired-release design) was implemented to estimate dam passage survival at Detroit Dam during 2014. The paired-release design is commonly used when evaluating passage survival at hydroelectric dams and has been described in detail by Burnham and others (1987), Skalski and others (2001), and Perry and others (2012). For our study, two groups of fish were released in the North Santiam River. Treatment fish were released upstream of Detroit Reservoir and control fish were released into the MTR. This release strategy was developed to achieve an outcome in which a large number ( $\geq 400$ fish) of treatment fish moved downstream and passed Detroit Dam. If this occurred, sufficient numbers of treatment and control fish would be available to provide robust dam passage survival estimates for Detroit Dam. However, the number of treatment fish that passed Detroit Dam during 2014 was very low and survival estimates that would have been obtained from analysis of paired-release data would have been highly uncertain. For this reason, we chose not to conduct the dam passage survival analysis for this report and the remainder of this report is focused on results of downstream migration timing and survival of the control group using the single release-recapture design. 


\section{Single-Release-Recapture Study Design}

Two Cormack-Jolly-Seber (CJS; Cormack, 1964; Jolly, 1965; Seber, 1965; Burnham and others, 1987) mark-recapture models were developed for analysis of data collected downstream of Minto Dam during our study. These models were based on a single-release recapture study design (hereinafter single release design) using control fish that were released in the MTR. The models were developed to estimate proportions of tagged fish detected on PIT tag antennas at the Bennett Dam complex and at Willamette Falls, and to estimate reach-specific survival for tagged fish that moved downstream of the MTR to Portland. Each of the CJS models are described below.

\section{Probability of Passive-Integrated-Transponder-Tag Detection at the Bennett Dam Complex and Willamette Falls}

A CJS model was developed to estimate detection probabilities for PIT-tag monitoring sites at the Bennett Dam complex and at Willamette Falls. This model incorporated acoustic detection records from the Salem, Wilsonville, and Portland sites with PIT tag detection records from the Bennett Dam complex and Willamette Falls. Detection probabilities at the acoustic telemetry sites generally were high $(>0.95)$, which provided the opportunity to obtain precise PIT tag detection probability estimates that described the proportion of tagged fish that were detected at each location as fish moved downstream. The CJS model relied heavily on acoustic detection records to estimate PIT tag detection probabilities. Thus, estimates applied only to the period during which acoustic-tagged control fish were detectable at acoustic monitoring sites based on the expected acoustic tag life (September 17, 2014, to November 22, 2014).

\section{Reach-Specific Survival Estimates}

A second CJS model was developed to estimate reach-specific survival for tagged fish moving downstream from the MTR to Portland. This model was unique because it provided unbiased survival estimates during September 2014-October 2015 by using the following data-(1) acoustic detection records from September 17 to November 22, 2014, which were based on the timing of the control release and the expected acoustic tag life; (2) PIT tag detection records from September 17, 2014, to October 1, 2015, which were based on the timing of the control release and the last date in which PITtagged fish were detected moving downstream and passing Willamette Falls; (3) acoustic tag-life data, which were empirically determined as previously described; and (4) acoustic tag-loss data, which were empirically determined as previously described. 
Negatively biased survival estimates would result if tagged fish moved downstream after their acoustic transmitter stopped working, or after losing their transmitter. These factors were accounted for by using techniques described by Townsend and others (2006). We estimated two probabilities, $P_{O}$ and $P_{R}$. The former $\left(P_{O}\right)$ was the probability that a transmitter was operating when tagged fish were passing the Bennett Dam complex and Willamette Falls. The latter $\left(P_{R}\right)$ was the probability that a transmitter was retained by tagged fish that were passing the two sites. We used data from the tag-life and tag-loss evaluations to develop Kaplan-Meier estimators used with travel time data to obtain group-averaged probabilities for $P_{O}$ and $P_{R}$ at downstream detection arrays. Travel times were calculated for individual fish from the time of release (in the MTR) to the time of arrival at the Bennett Dam complex and at Willamette Falls (using PIT tag detections at each site). These travel times were then applied to the Kaplan-Meier estimators using SAS (version 9.3 of the SAS System for Windows Copyright ${ }^{\complement} 2002-$ 2010, SAS Institute Inc., Cary, North Carolina; Allison, 2009) to obtain separate estimates for $P_{O}$ and $P_{R}$ at the Bennett Dam complex and at Willamette Falls. These estimates were then incorporated into the likelihoods for the CJS model using Program USER (Lady and others, 2008), which allowed us to obtain reach-specific survival estimates that were not biased by tag life or tag loss. The transmitter loss evaluation was terminated 162 days post-tagging so we assumed that no tag loss occurred after 162 days.

\section{Results}

\section{Dam Operations and Environmental Conditions}

Reservoir water elevation and forebay water temperature decreased gradually from early August to late October at Detroit Dam (fig. 4). The reservoir water elevation was 1,556 ft on August 11, 2014, and decreased to $1,497 \mathrm{ft}$ by October 28,2014 . Similarly, surface-water temperatures were $20.1^{\circ} \mathrm{C}$ on August 11,2014 , and decreased to $14.7^{\circ} \mathrm{C}$ by October 28,2014 . Total project discharge varied little during August (approximately $1,000 \mathrm{ft}^{3} / \mathrm{s}$ ) and was nearly evenly split between the powerhouse and spillway (fig. 4). During September, there was a slight increase in total project discharge, and most water was passed through the powerhouse. During October, total project discharge increased to about $3,000 \mathrm{ft}^{3} / \mathrm{s}$, and the spillway was not used (fig. 4). All October discharge passed through the powerhouse and regulating outlet. 

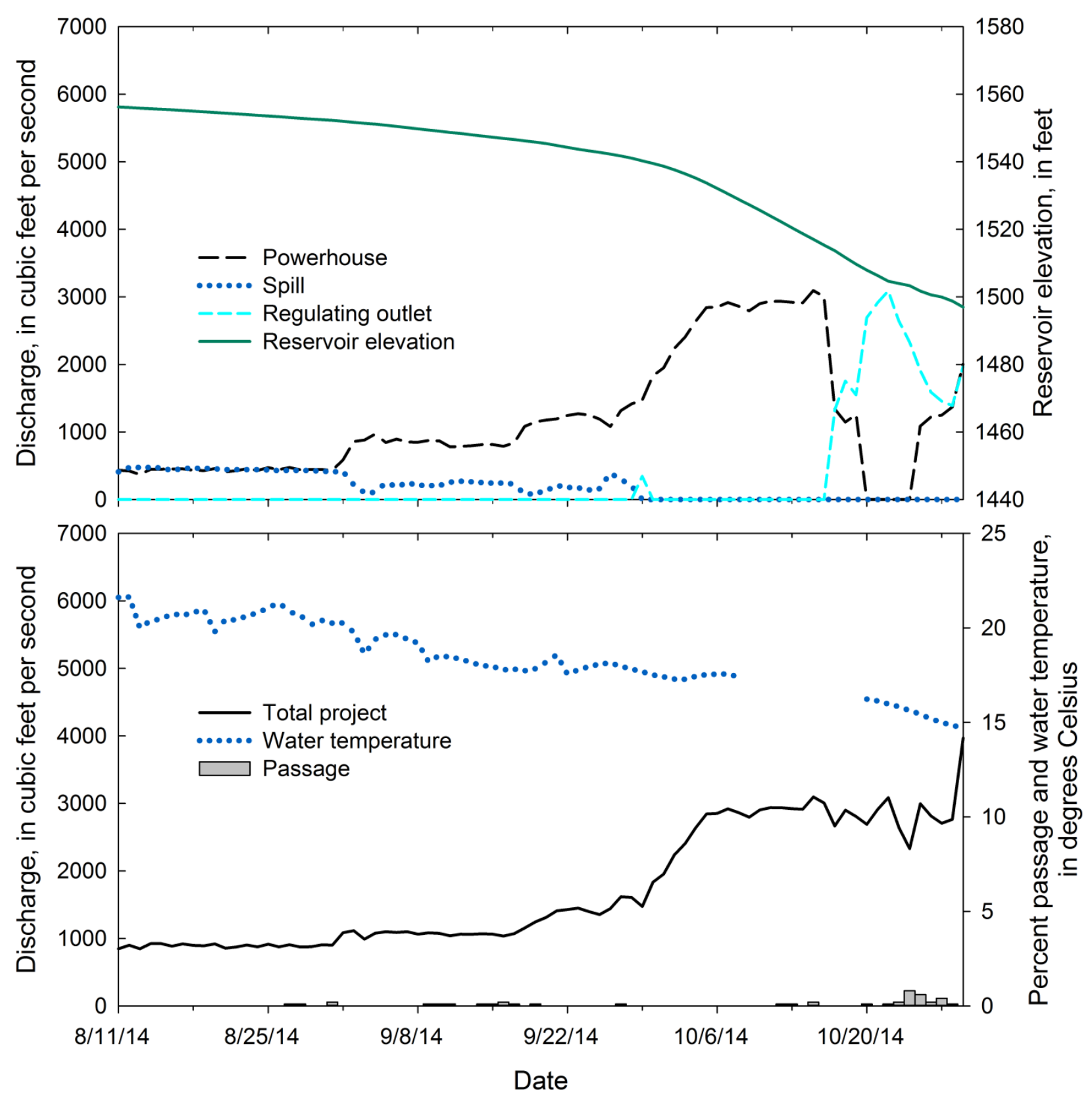

Figure 4. Graphs showing daily mean operations and environmental conditions at Detroit Reservoir, Oregon, August 11-October 28, 2014, when fish were released and detected in the reservoir. Additionally, daily passage of juvenile Chinook salmon was plotted as a percentage of fish released near the head of the reservoir (vertical bars). 


\section{Fish Handling, Tagging, and Release}

A total of 1,692 Chinook salmon were tagged with acoustic transmitters during August 4-9, 2014. These included 997 treatment fish and 670 control fish (table 2). All treatment fish were released alive and the control fish were comprised of 645 live and 25 euthanized fish. The average pre-tag holding time was 22.3 hours (range 20.5-23.9) for treatment fish and 21.9 hours (range 19.4-25.8) for control fish. The tagged fish were an average of approximately $102 \mathrm{~mm}$ in fork length and $5 \mathrm{~g}$ in weight. There was no significant difference in either fork length or weight between groups (one-way GLM; $P=$ 0.9637; $P=0.2902$ ). Tag-weight-to-body-weight ratios (tag weight=acoustic transmitter weight + PIT tag weight) averaged 3.2 percent (range 1.7-5.9 percent). Water temperatures during tagging ranged from 10.3 to $15.4{ }^{\circ} \mathrm{C}$.

The treatment fish were released on August 11, 2014, 2-7 days after tagging, at the Blowout Road Bridge on the North Santiam River. The group was comprised of 997 acoustic+PIT fish and 9,036 PIT fish. The paired-release design assumes that treatment and control fish will experience similar conditions within common migratory reaches, and the primary difference between the two groups is the migratory experience that treatment fish encounter between their release location and the release location for the control fish. Thus, the timing of the control release group was to occur when about onehalf of the treatment fish had arrived at the control release site location. Detections at Minto Dam were monitored daily following the treatment release, and control fish were released about 1 month after the treatment fish due to the low passage rates that occurred at Detroit Dam. The release of control fish occurred in the MTR (at Packsaddle County Park) on September 17, 2014, 43-48 days after acoustic tagging occurred and used the fish transport truck previously described. A total of 45 live control fish and 2 dead control fish were not released or were omitted from data analyses for the following reasons - 32 live control fish shed their acoustic transmitter during the post-tagging holding period; 11 live control fish were released with acoustic transmitters that were not operational based on absence of pre-release detections in the MFH holding pond; 2 live control fish died during the post-tagging holding period; 1 dead control fish was removed from the MFH holding pond (probably by a predator) during the post-tagging holding period; and 1 dead control fish shed its acoustic transmitter during the posttagging holding period. As a result, the control release group was comprised of 625 acoustic+PIT live control fish, 23 acoustic+PIT dead control fish, and 9,324 PIT tag-only fish.

Table 2. Summary statistics of fork length and weight of acoustic- and Passive-Integrated-Transponder-tagged hatchery Chinook salmon used in data analyses at Detroit Reservoir, Oregon, 2014.

$[N$, the number of fish; $\mathrm{SD}$, standard deviation $]$

\begin{tabular}{lcccccccc}
\hline \multirow{2}{*}{ Release group } & \multirow{2}{*}{$\mathbf{N}$} & \multicolumn{2}{c}{ Fork length (millimeters) } & & \multicolumn{3}{c}{ Weight (grams) } \\
\cline { 3 - 5 } \cline { 6 - 8 } & & Mean & SD & Range & & Mean & SD & Range \\
\hline Treatment & 997 & 102.7 & 5.3 & $95-123$ & & 13.1 & 2.3 & $8.9-23.7$ \\
Control: live & 645 & 102.7 & 5.1 & $95-116$ & & 12.9 & 2.2 & $7.0-19.4$ \\
Control: dead & 25 & 102.4 & 4.9 & $96-112$ & & 12.7 & 1.9 & $9.8-15.6$ \\
\hline
\end{tabular}




\section{Removal of Dead Tags Prior to Release}

Twelve of the acoustic tags within control fish and none of the acoustic tags within the treatment fish were undetected during the 64-hour pre-release period. The 12 undetected tags were removed from the final detection dataset. Eleven of the non-detected tags were from fish in the live control holding pond that contained approximately 10,000 Chinook salmon (acoustic+PIT- and PIT-only fish). The other non-detected tag was from a fish in the dead control holding pond that contained 25 Chinook salmon (acoustic+PIT-only). Each of the dead control fish was handled at the time of release when the euthanasia process was occurring. At that time, the fish with the non-detected tag was missing from the holding pond. Because terrestrial and avian predators can access the MFH holding ponds, we suspect that the fish was preyed upon at some point during the post-tag holding period. Predation events could also explain nondetection events in the live control pond, but it was not possible for us to make this determination due to the large number of fish that were being held at that location.

\section{Transmitter Life Expectancy, Transmitter Loss, and Downstream Movement of Dead Fish}

Results from the tag-life study showed that three transmitters expired prematurely, but most of the transmitters operated for at least 80 days. The transmitters that stopped working earlier than expected were last detected 50.0,66.2, and 70.1 days after they began operating. Most (72 percent) of the transmitters expired 85-95 d after activation. Median tag-life was $90.5 \mathrm{~d}$ and maximum tag-life was $106.5 \mathrm{~d}$ (fig. 5). The 90th percentile of tag-life during the study, the follow-up period used in evaluation of travel times and dam passage, was $82.1 \mathrm{~d}$ (fig. 5).

A total of 7.8 percent of the acoustic-tagged fish shed transmitters during the 162-d study (fig. 6 ). Because tag-loss did not differ between feeding regimes (Wilcoxon test, chi-square $=0.8824$, $P=0.3476$ ), data from both groups were pooled for analysis. All fish retained transmitters during the initial $22 \mathrm{~d}$ post-tagging period, but shedding occurred from 23 to $118 \mathrm{~d}$ post-tagging. Some fish were removed for necropsy at 42 and $106 \mathrm{~d}$, reducing the total number of fish available in the dataset. In the field study, tagged control fish were held for at least $39 \mathrm{~d}$ prior to release, which allowed us to monitor tag-loss of that group during that period. In the laboratory study, three fish shed tags during the initial 39 days of the evaluation, so these events were right-censored for estimation of transmitter shedding. Six of the Chinook salmon that were tagged for the tag-loss study shed their transmitter between 39 and 162 days.

Detection records at acoustic monitoring sites located downstream of the MTR were queried to determine if any dead control fish drifted downstream and were detected. None of the dead control fish were detected downstream of the MTR. 


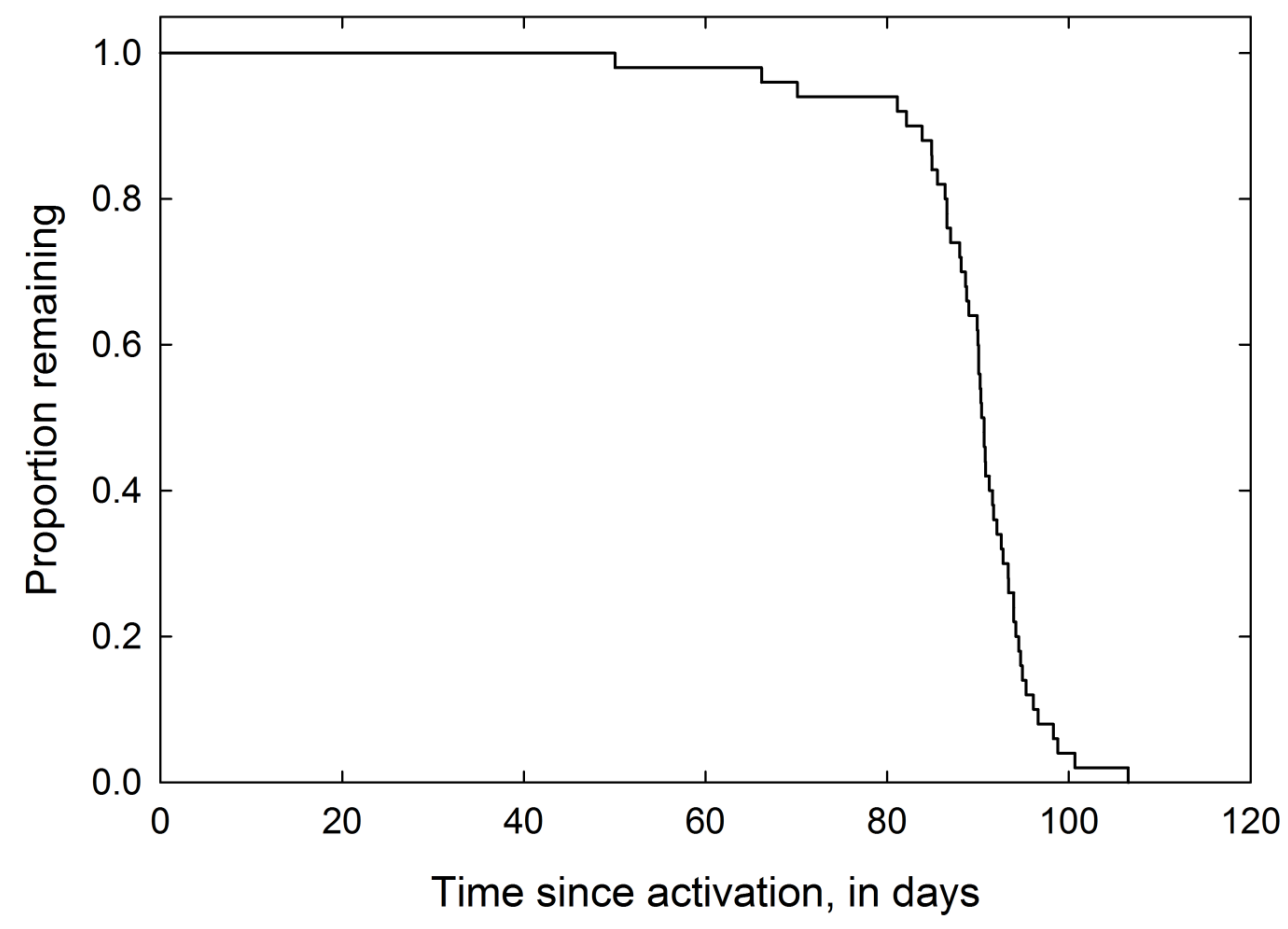

Figure 5. Graph showing survival distribution function of tag life from activation to expiration for the acoustic tags used at and downstream of Detroit Reservoir, Oregon, 2014-15.

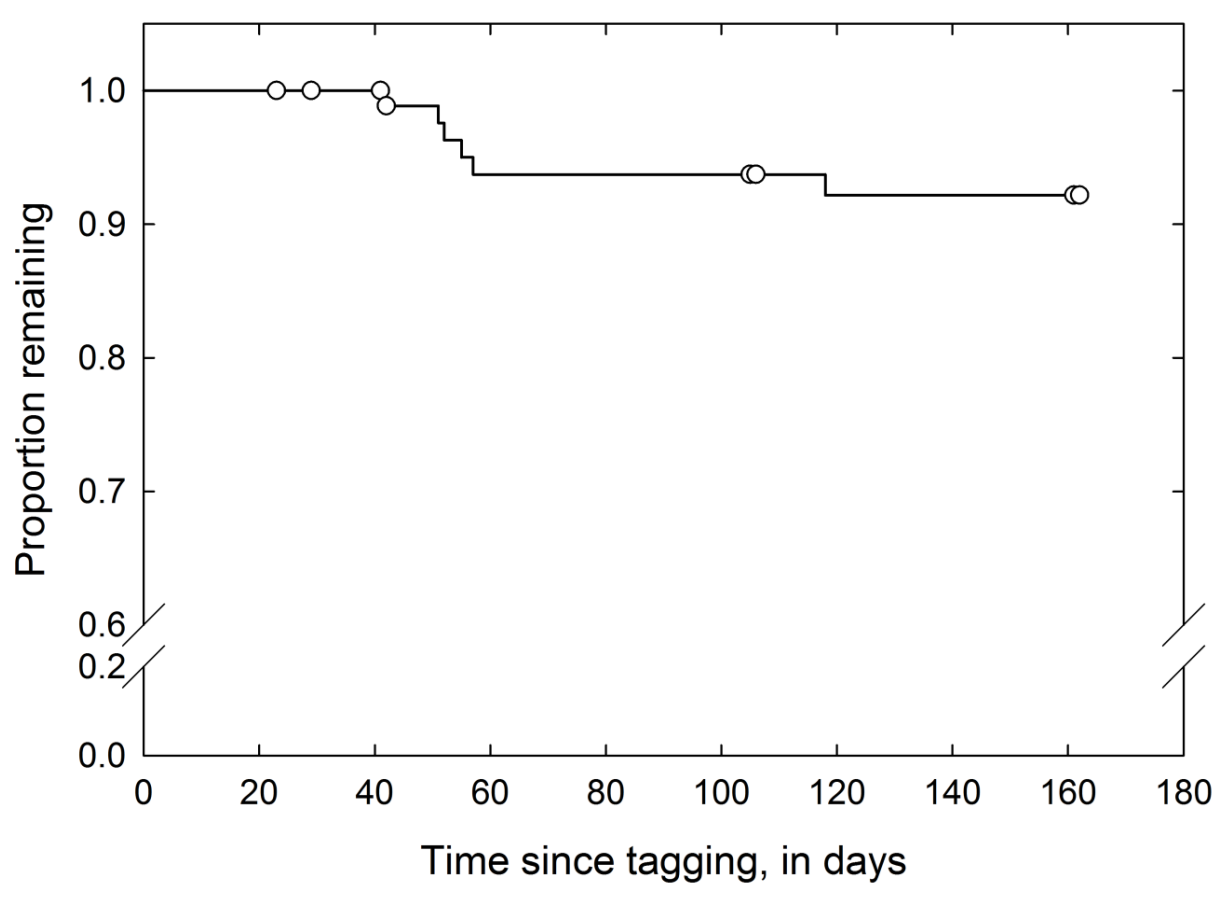

Figure 6. Graph showing survival distribution function of transmitter loss from a laboratory study conducted at the Columbia River Research Laboratory, Washington, 2014-15. Observations are right-censored (open circles) when fish were removed for necropsy or at the end of the study if no event occurred. Observations were also rightcensored if the event occurred prior to the control release (39 days after tagging). 


\section{Forebay Arrival, Passage at Detroit Dam, and Detection at Downstream Gates}

Forebay arrival and dam passage of treatment fish were lower than expected during 2014. A total of 572 of the 997 treatment fish released (57.4 percent) were detected in the forebay of Detroit Dam within the 82.1-day follow-up period (table 3). The FAE for tagged fish in 2014 was significantly lower $(P<0.0001)$ than any of the previous releases that were conducted during autumn months in 2012 and 2013 (table 3). Median travel time from the release site to the dam forebay was 60.2 days in 2014, which was substantially slower than travel times in 2012 and 2013 (fig. 7). A total of 43 fish were detected passing Detroit Dam within the follow-up period. This accounted for 4.3 percent of the acoustic+PIT-tagged fish that were released upstream of Detroit Reservoir and 7.5 percent of the acoustic+PIT-tagged fish that arrived in the dam forebay. About one-half of the Chinook salmon passing the dam passed through the RO (54.8 percent), and the remaining fish passed through the spillway (31.0 percent) or the turbines (14.3 percent; table 4$)$.

The number of tagged fish that passed Detroit Dam and then moved through downstream reaches was low (tables 5-6). A total of 24 acoustic+PIT-tagged fish (2.4 percent) were detected in the forebay of Big Cliff Dam, and 12 fish or less were detected at each of the remaining downstream monitoring sites (tables 5 and 6). Few fish were detected at sites downstream of Minto Dam after October 2014. Given that very few treatment fish were detected downstream of Detroit Dam, the remaining analyses in this report were only conducted using detections of control fish.

Table 3. Forebay arrival metrics and 95-percent confidence intervals for acoustic-tagged Chinook salmon at Detroit Dam, Oregon, 2012-14.

[Statistical results are also presented as $P$-values from a chi-square test of independence that was conducted using a Bonferroni correction to control for multiple pairwise comparisons]

\begin{tabular}{|c|c|c|c|c|c|c|}
\hline Year & Release month & $\begin{array}{l}\text { Number of fish } \\
\text { released }\end{array}$ & $\begin{array}{l}\text { Number of fish } \\
\text { detected in } \\
\text { forebay }\end{array}$ & $\begin{array}{c}\text { Estimate of } \\
\text { forebay arrival } \\
\text { efficiency }\end{array}$ & $\begin{array}{c}95 \text { percent } \\
\text { confidence } \\
\text { interval }\end{array}$ & P-value \\
\hline \multirow[t]{3}{*}{2012} & September & 84 & 65 & 0.774 & $0.674-0.850$ & 0.060 \\
\hline & October & 90 & 69 & 0.767 & $0.670-0.842$ & 0.069 \\
\hline & November & 87 & 65 & 0.747 & $0.647-.0827$ & 0.225 \\
\hline \multirow[t]{3}{*}{2013} & September & 78 & 54 & 0.692 & $0.583-0.784$ & 1.000 \\
\hline & October & 76 & 65 & 0.855 & $0.759-0.917$ & ${ }^{1} 0.001$ \\
\hline & November & 149 & 109 & 0.732 & $0.655-0.796$ & 0.101 \\
\hline 2014 & August & 997 & 572 & 0.574 & $0.543-0.604$ & ${ }^{1}<0.001$ \\
\hline
\end{tabular}

\footnotetext{
${ }^{1}$ Releases that were significantly different than others in the group.
} 


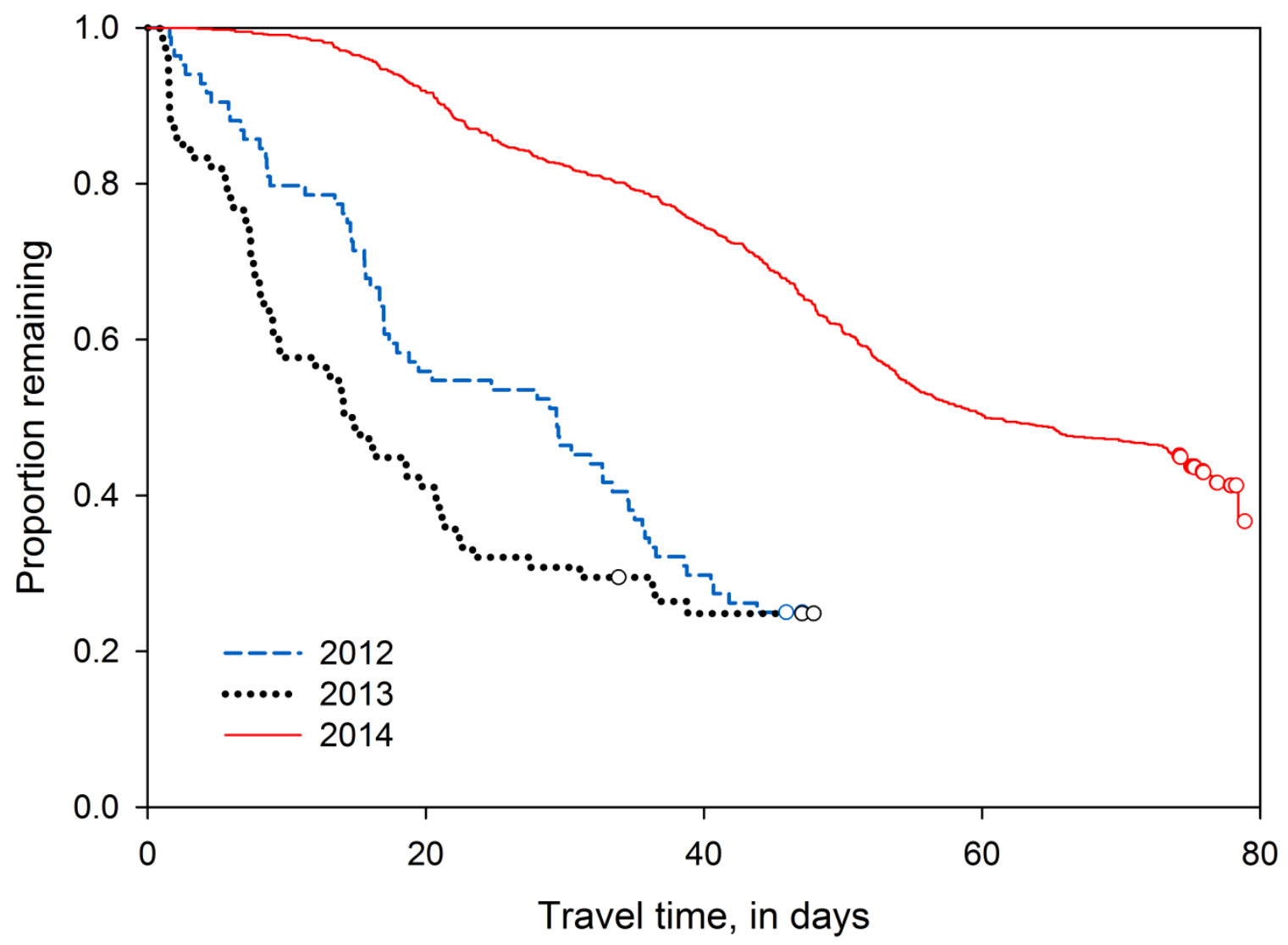

Figure 7. Graph showing survival distribution of travel time from release on the North Santiam River to the forebay in Detroit Reservoir, Oregon, of acoustic-tagged Chinook salmon, 2012-14. Observations are right-censored (open circles) on October 28 each year, which was the 90th percentile of the tag life for the 2014 fish. Fish from 2012 and 2013 were released during September each year and fish from 2014 were released during August.

Table 4. Seasonal passage metric estimates and 95-percent confidence intervals from the study of acoustictagged Chinook salmon at Detroit Dam, Oregon, 2014.

\begin{tabular}{lcccc}
\hline \multicolumn{1}{c}{ Metric } & $\begin{array}{c}\text { Number of fish } \\
\text { in numerator }\end{array}$ & $\begin{array}{c}\text { Number of fish } \\
\text { in denominator }\end{array}$ & $\begin{array}{c}\text { Passage metric } \\
\text { estimate }\end{array}$ & $\begin{array}{c}\text { 95-percent } \\
\text { confidence } \\
\text { interval }\end{array}$ \\
\hline Dam passage efficiency (DPE) & 43 & 572 & 0.075 & $0.056-0.100$ \\
Fish passage efficiency (FPE) & 36 & 42 & 0.837 & $0.700-0.919$ \\
Spillway passage efficiency (SPE) & 13 & 42 & 0.310 & $0.191-0.460$ \\
Turbine passage efficiency (TPE) & 6 & 42 & 0.143 & $0.067-0.278$ \\
Regulating outlet efficiency (ROE) & 23 & 42 & 0.548 & $0.400-0.688$ \\
\hline
\end{tabular}


Table 5. Number of treatment and control fish released and detected at acoustic telemetry and Passive Integrated Transponder (PIT) tag monitoring sites in the North Santiam and Willamette Rivers, Oregon, within the 90th percentile of the tag life of acoustic transmitters used during the study.

[Numbers in parentheses are percentage of fish]

\begin{tabular}{lcccc}
\hline \multirow{2}{*}{ Description } & \multicolumn{2}{c}{ Treatment fish } & \multicolumn{2}{c}{ Control fish } \\
\cline { 2 - 4 } & PIT-tagged & Acoustic+PIT-tagged & PIT-tagged & Acoustic+PIT-tagged \\
\hline Number of fish released & 9,036 & 997 & 9,324 & \\
Detroit Dam Forebay & & $572(57.4)$ & & \\
Big Cliff Dam & & $24(2.4)$ & \\
Minto Dam & & $9(0.9)$ & \\
Bennett Dam & $52(0.5)$ & $9(0.9)$ & $1,349(14.5)$ & $242(38.1)$ \\
Salem & & $12(1.2)$ & & $257(40.4)$ \\
Wilsonville & $9(0.9)$ & & \\
Willamette Falls & $40(0.4)$ & $2(0.2)$ & & $136(21.4)$ \\
Portland & & $5(0.5)$ & $53(8.3)$ \\
& & & & $98(15.4)$ \\
\hline
\end{tabular}

Table 6. Monthly detections of acoustic+PIT-tagged Chinook salmon on Passive-Integrated-Transponder-tag antennas at the Bennett Dam complex and Willamette Falls, Oregon, 2014-15.

[Numbers in parentheses are percentage of fish]

\begin{tabular}{lcccc}
\hline \multirow{2}{*}{$\begin{array}{c}\text { Month and year } \\
\text { of detection }\end{array}$} & \multicolumn{2}{c}{$\begin{array}{c}\text { Treatment release group } \\
(\mathbf{n = 9 9 7 )}\end{array}$} & \multicolumn{2}{c}{$\begin{array}{c}\text { Control release group } \\
(\mathbf{n}=625)\end{array}$} \\
\cline { 2 - 5 } & Bennett Dam complex & Willamette Falls & Bennett Dam complex & Willamette Falls \\
\hline September 2014 & $5(0.5)$ & $1(0.1)$ & $91(14.6)$ & $11(1.8)$ \\
October 2014 & $1(0.1)$ & $1(0.1)$ & $26(4.2)$ & $42(6.7)$ \\
November 2014 & $1(0.1)$ & $1(0.1)$ & $3(0.5)$ & $1(0.2)$ \\
December 2014 & $2(0.2)$ & $0(0.0)$ & $2(0.3)$ & $0(0.0)$ \\
\hline January 2015 & $0(0.0)$ & $0(0.0)$ & $1(0.2)$ & $0(0.0)$ \\
February 2015 & $0(0.0)$ & $0(0.0)$ & $0(0.0)$ & $1(0.2)$ \\
March 2015 & $0(0.0)$ & $0(0.0)$ & $0(0.0)$ & $5(0.8)$ \\
April 2015 & $0(0.0)$ & $0(0.0)$ & $0(0.0)$ & $0(0.0)$ \\
May 2015 & $0(0.0)$ & $1(0.1)$ & $0(0.0)$ & $0(0.0)$ \\
June 2015 & $1(0.1)$ & $0(0.0)$ & $0(0.0)$ & $0(0.0)$ \\
July 2015 & $0(0.0)$ & $0(0.0)$ & $0(0.0)$ & $0(0.0)$ \\
August 2015 & $0(0.0)$ & $0(0.0)$ & $0(0.0)$ & $0(0.0)$ \\
September 2015 & $0(0.0)$ & $0(0.0)$ & $0(0.0)$ & $0(0.0)$ \\
\hline Total & $10(1.0)$ & $4(0.4)$ & $123(19.7)$ & $60(9.6)$ \\
\hline
\end{tabular}




\section{Probability of Passive-Integrated-Transponder-Tag Detection at the Bennett Dam Complex and Willamette Falls}

Control fish were released into the MTR in mid-September and began passing Bennett Dam and Willamette Falls shortly thereafter (fig. 8). Travel times from the MTR to the Bennett Dam complex were significantly different between acoustic+PIT-tagged fish and PIT-tagged fish (Wilcoxon chisquare test, $P=0.001$ ) but were not significantly different from the MTR to Willamette Falls (Wilcoxon chi-square test, $P=0.833$ ). Most of the passage at these locations occurred within 40 days of release, but some fish were still passing Willamette Falls more than 6 months after release (fig. 8). However, the acoustic transmitters were operational during September-November, when river flows were relatively low (fig. 9). The CJS model estimate for detection probability of PIT-tagged fish at the Bennett Dam complex was 0.257 (95-percent confidence interval 0.206-0.308). A total of 402 acoustic+PIT-tagged fish were detected on acoustic hydrophones, PIT tag antennas, or both, at the Bennett Dam complex. Based on these detections, 38.3 percent of the fish were only detected at Upper Bennett Dam, 39.8 percent were only detected in the Stayton Canal, and 21.9 percent were detected at both sites. A total of 123 acoustic+PIT-tagged fish were detected on PIT tag antennas at the Bennett Dam complex and 9.0 percent of the fish were only detected at Upper Bennett Dam, while 91.0 percent of the fish were only detected in the Stayton Canal. Acoustic hydrophones in the Stayton Canal detected a total of 225 acoustic+PIT-tagged fish (56.0 percent of those detected at the Bennett Dam complex), but only 47.1 percent of those fish were subsequently detected on PIT tag antennas at that location. Telemetry records from tagged fish in the Stayton Canal showed that 80 percent of the acoustic-tagged fish spent less than 1 day in the canal, and the median residence time at that location was 6.5 hours. However, 12.7 percent of the tagged fish had residence times in the canal between 7 and 37 days.

The probability of tagged fish passing through and being detected by the PIT-tag antennas at Willamette Falls was 0.398 (95-percent confidence interval 0.308-0.488). A total of 53 acoustic+PITtagged fish were detected on PIT tag antennas at the dam and all these fish were detected in the fish bypass rather than the adult fish ladder. 


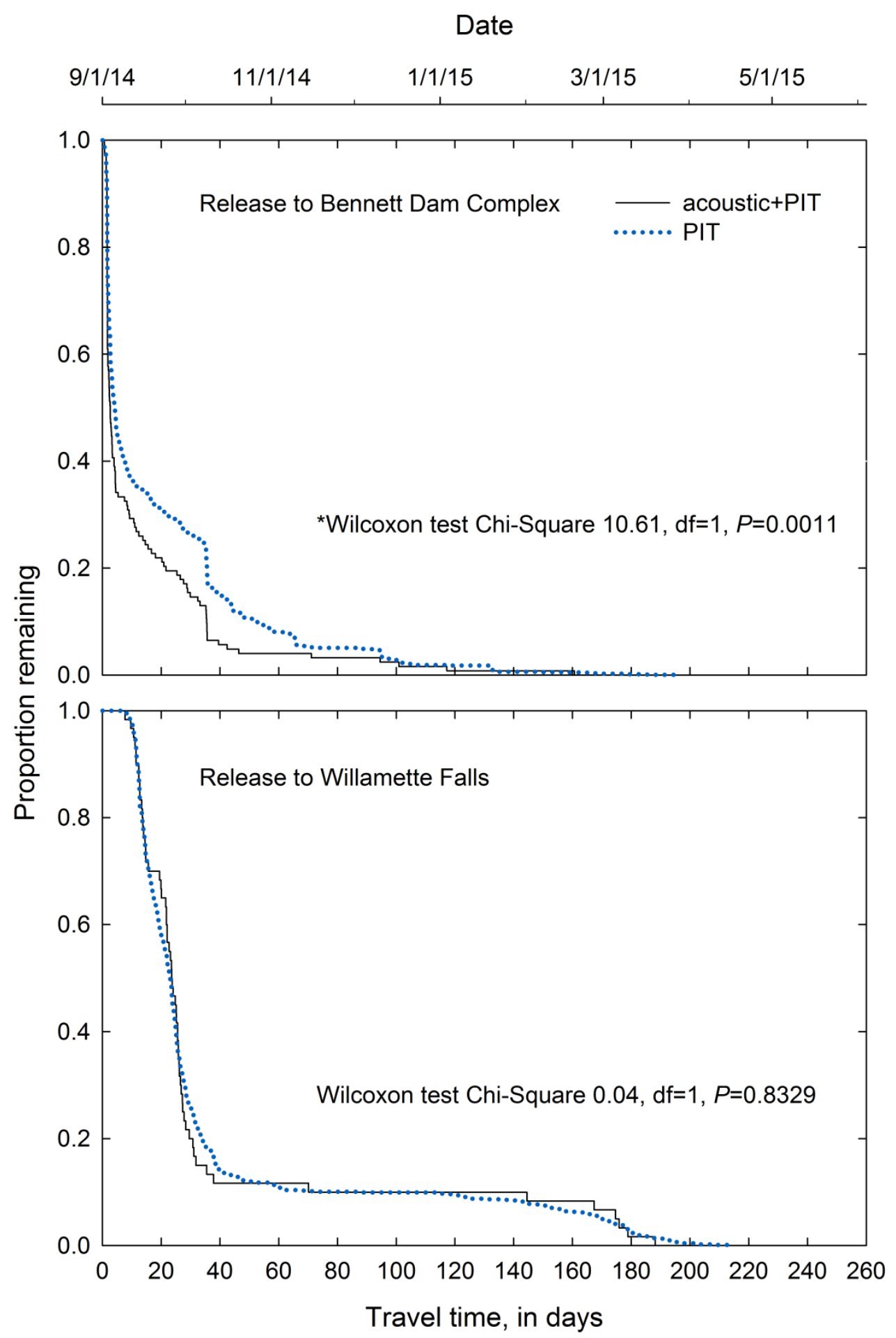

Figure 8. Graphs showing survival distribution function of travel time from the control release near Minto Dam to the Bennett Dam complex and from the control release near Minto Dam to Willamette Falls, Oregon, of tagged Chinook salmon, 2014. Asterisk ( $\left.{ }^{*}\right)$ indicates significant difference between travel times. 

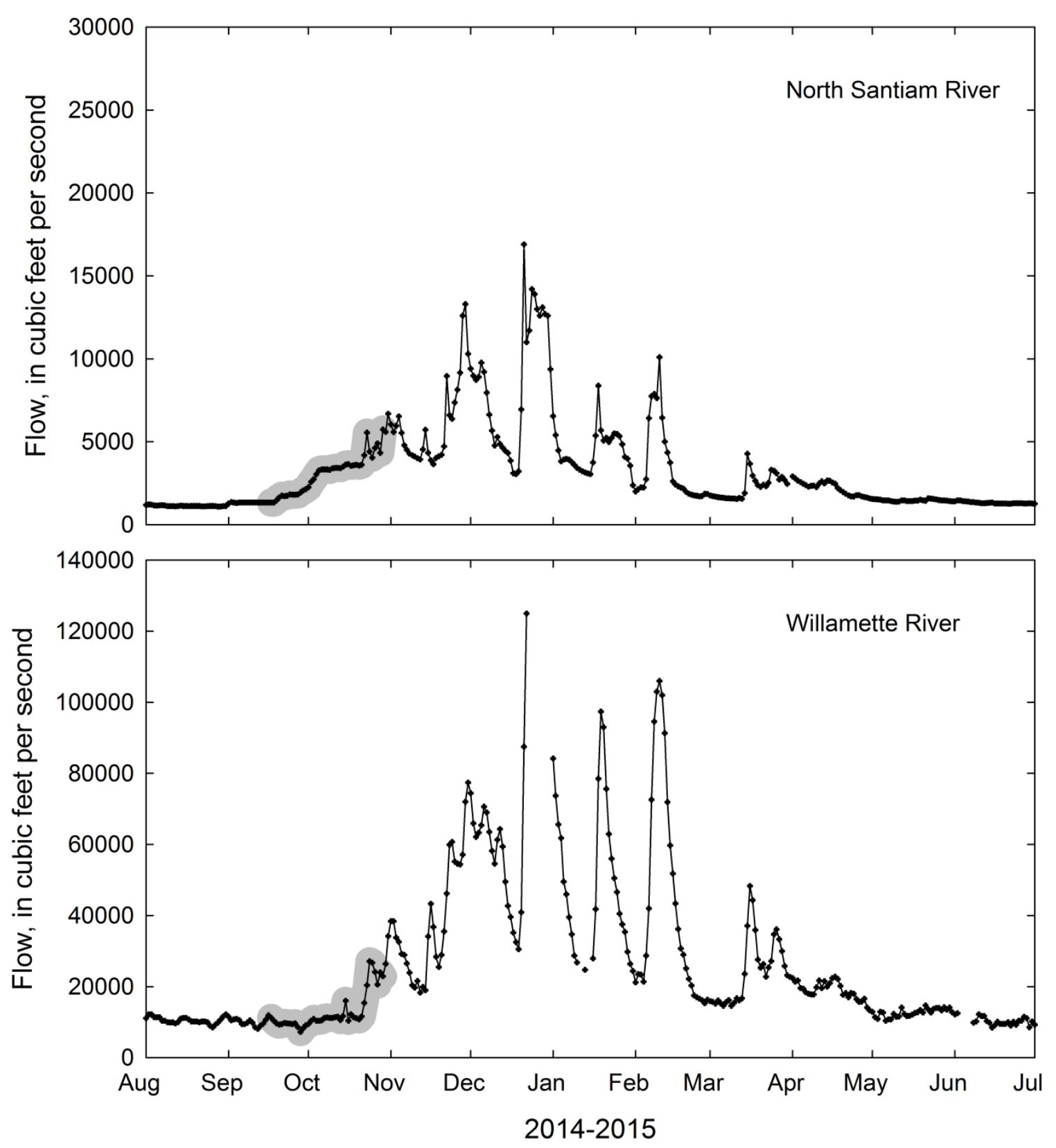

Figure 9. Graphs of daily river flows in the North Santiam River, near Stayton, Oregon, and the Willamette River in Portland, Oregon, August 2014-July 2015. The gray highlight identifies the period during which Passive-IntegratedTransponder-tag detection probability estimates were obtained for the Bennett Dam complex and Willamette Falls. 
Reach-Specific Survival Estimates

Tagged fish experienced substantial mortality as they moved downstream through the study area. The probability of tagged fish arriving at the Bennett Dam complex with an operating acoustic transmitter $\left(P_{O}\right)$ was 0.945 and the probability of retaining the transmitter $\left(P_{R}\right)$ until arrival at Bennett Dam was 0.972 . The $P_{O}$ for arrival at Willamette Falls was 0.869 and $P_{R}$ was 0.940 . These probabilities were used to provide unbiased (adjusted) estimates for migration survival from the MTR to the Bennett Dam complex (0.844) and from the Bennett Dam complex to Portland (0.279; table 7). Overall, survival from the MTR to Portland was estimated at 0.236. We calculated survival per $100 \mathrm{rkm}$ for each reach to provide standardized estimates that could be used to compare among reaches. These estimates showed that survival rates were higher in the Minto Dam to Bennett Dam reach $(0.634$ per $100 \mathrm{~km})$ than in the Bennett Dam to Portland reach (0.534 per $100 \mathrm{~km}$; table 7).

Table 7. Reach-specific survival estimates from a Cormack-Jolly-Seber mark-recapture model for juvenile Chinook salmon in the North Santiam, Santiam, and Willamette Rivers, Oregon, 2014.

\begin{tabular}{lcccc}
\hline \multicolumn{1}{c}{ Reach } & $\begin{array}{c}\text { Reach length } \\
\text { (kilometers) }\end{array}$ & $\begin{array}{c}\text { Survival } \\
\text { estimate }\end{array}$ & $\begin{array}{c}\text { 95-percent } \\
\text { confidence } \\
\text { interval }\end{array}$ & $\begin{array}{c}\text { Survival per 100 } \\
\text { river kilometers }\end{array}$ \\
\hline Minto Dam tailrace to Bennett Dam complex & 37.2 & 0.844 & $0.795-0.893$ & 0.634 \\
Bennett Dam complex to Portland & 203.0 & 0.279 & $0.234-0.324$ & 0.534 \\
Minto Dam tailrace to Portland & 240.2 & 0.236 & $0.197-0.275$ & 0.549 \\
\hline
\end{tabular}

\section{Discussion}

Downstream movement and dam passage rates for treatment fish were lower than expected during 2014, which prevented us from estimating dam passage survival at Detroit Dam. Reservoir travel time and forebay arrival rates were substantially lower in 2014 than in 2012 and 2013 for groups of fish that were released at a common location near the HOR. There are several factors that differed between the 2012-13 and 2014 release groups that could be responsible for this. North Santiam River flows upstream of Detroit Reservoir were similar during late summer and early autumn in 2012-14, but during 2014, treatment fish were released into Detroit Reservoir during August when reservoir water temperatures in the upper $6 \mathrm{~m}$ exceeded $22^{\circ} \mathrm{C}$. Releases for the 2012 and 2013 studies were conducted during September, October, and November when reservoir water temperatures ranged from 7 to $21{ }^{\circ} \mathrm{C}$. Other studies have shown that juvenile Chinook salmon are less likely to migrate during August when water temperatures approach or exceed $20^{\circ} \mathrm{C}$. In the Cowlitz River, Washington, Kock and others (2015) released groups of radio-tagged juvenile Chinook salmon into Lake Scanewa during July and August 2014. Most tagged fish that were released during July moved downstream and passed Cowlitz Falls Dam, whereas many of the fish that were released during August, when water temperatures exceeded $18{ }^{\circ} \mathrm{C}$, stopped migrating and remained in Lake Scanewa. Similarly, in the Snake River, Washington, radio-tagged juvenile Chinook salmon released upstream of Lower Granite Reservoir in June and early July were much more likely to move downstream and enter the reservoir than tagged fish that were released in late July (Tiffan and Connor, 2003, 2004). Water temperatures in that study during June and early July were $18{ }^{\circ} \mathrm{C}$ or less, whereas temperatures during late July release periods exceeded $20^{\circ} \mathrm{C}$. Another factor that may have contributed to decreased movements by treatment fish during 2014 is the stock of fish that were tagged. During 2012 and 2013, study fish were wild surrogates that were reared by Oregon State University as part of their Willamette River Basin wild surrogate program (D.J. 
Noakes and others, Oregon State University, written commun., February 2013) This program was developed to support research efforts in the Willamette River Basin by producing hatchery-reared juvenile salmonids that exhibit desired phenotypes of naturally reared fish. During 2014, we used hatchery-reared juvenile Chinook salmon from the MFH. Empirical data describing potential differences in fish behavior between the two stocks used during our studies is not currently available. However, this factor differed between the 2014 and 2012-13 studies and is worthy of consideration. Study fish from 2012 to 2013 were also larger than study fish from 2014. Mean fork length of tagged fish in 2012 and 2013 was 141.8 and $149.1 \mathrm{~mm}$, respectively, compared to $102.7 \mathrm{~mm}$ in 2014 (Beeman and others, 2014; Beeman and Adams, 2015). Tag burden was also lower for the 2012-13 fish (1.3 percent in 2012; 1.4 percent in 2013; 3.2 percent in 2014), owing to their larger body size.

Embedding groups of acoustic+PIT-tagged fish within larger groups of PIT-tag-only fish was insightful for determining if acoustic-tag presence affected the behavior of study fish. Travel rates in the $37.2 \mathrm{rkm}$ reach between Minto Dam and the Bennett Dam complex were faster for acoustic+PIT-tagged fish than PIT-tag-only fish. However, the shape of the Kaplan-Meier curves for the two groups were nearly identical, which suggests that migration behavior was similar between groups. For example, more than one-half of the fish from each group arrived at Bennett Dam within 10 days of release, and a substantial number of fish arrived at the dam near the 40-day post-release mark. At Willamette Falls, travel time curves were nearly identical, and there was not a statistically significant difference between groups. Additionally, the percentage of acoustic+PIT-tagged fish and PIT-tag-only fish that were detected at Willamette Falls was similar within each release group (table 5). Given these relationships, there appeared to be a short-term effect of acoustic-tag presence on migration behavior and this finding agrees with observations of tag effects on short-term behavior of juvenile salmon in laboratory and field studies (Perry and others, 2014). However, the existing data suggest that migration behaviors were similar for acoustic+PIT-tagged fish and PIT-tag-only fish when examined over the entire study area and duration of the study. This observation has important implications for future studies because there are distinct advantages to using active transmitters (radio or acoustic) with PIT tags in fisheries studies. The active transmitters have high detection probabilities that are critical for determining near-dam fish behavior, describing two- or three-dimensional fish movement paths, determining route of passage through areas of interest, and estimating migration or dam-passage survival using small sample sizes compared to achieving similar precision using PIT tags. Alternatively, PIT tags are inexpensive and are detectable for the entire lifespan of the tagged fish. In our study, the acoustic transmitters allowed us to generate precise estimates of PIT tag detection probabilities at the Bennett Dam complex and Willamette Falls. The PIT tags allowed us to monitor fish movements during the months after the acoustic transmitters stopped working and to generate survival estimates that accounted for tag failure and tag loss. Estimating travel times with PIT tags was superior to the use of active tags used in other studies (Townsend and others, 2006) because they are not limited by a battery and provide unbiased estimates of travel time.

Our estimates of detection probabilities of PIT-tagged fish at the Bennett Dam complex and at Willamette Falls may be useful for future evaluations in the Willamette River Basin. The use of PIT tags to monitor juvenile salmonids is very common because it provides a cost-effective option for monitoring fish movement patterns and determining smolt-to-adult return rates for various fish stocks. In the Willamette River Basin, reliable estimates of PIT-tag detection probabilities at Willamette Falls are critical because the dam is the downstream-most location where PIT-tagged fish are reliably detected as they migrate to the ocean. As a result, PIT-tag detections at Willamette Falls are routinely used to make inferences about outmigration timing and survival for various juvenile salmon stocks in the basin. A key uncertainty in these inferences is the proportion of tagged fish in a given population that are detected at Willamette Falls. Fishery managers have generally assumed that about 10 percent of 
the PIT-tagged fish are detected as they pass the project, but the detection probabilities of the PIT tag antennas can be highly variable and are likely affected by river flow and equipment that is intermittently operated near the antennas (Nick Ackerman, Portland General Electric, written commun., January 2015). Karchesky and others (2010) showed that river flows affected the proportion of fish passing through various routes at the dam. They found that increasing river flow resulted in increased passage over the "Falls," which is not monitored by PIT-tag antennas. Forty percent of the tagged fish were detected on PIT-tag antennas while passing Willamette Falls during September and October 2014. Although this measurement is substantially higher than previously assumed, our data were collected when river flows were low and spill was not occurring. Thus, our estimates apply only to flow conditions during our study period. Given the importance of PIT-tag data collection at Willamette Falls, future evaluations should be conducted to provide reliable estimates of detection probabilities at the dam, under the full range of river flows and operating conditions. At the Bennett Dam complex, we estimated that 26 percent of the PIT-tagged fish were detected as they moved downstream. River flows are likely a key factor in detection probabilities at that location as well because several dams are present and water passage over the spillways depends on river flow. Deploying PIT-tag antennas in the Stayton Canal was a logical option because the canal is not dewatered seasonally, and fish that are entrained in the canal are returned to the river through an outlet pipe that is conducive to PIT tag detection. Analysis of the PIT-tag detection records at the Bennett Dam complex confirmed this assumption. Detections on PIT-tag antennas showed that 91 percent of the acoustic+PIT-tagged fish that were detected at the Bennett Dam complex were detected in the Stayton Canal.

Migration survival was low during the study. Approximately 84 percent of the tagged fish that were released in the MTR survived to the Bennett Dam complex, but only 28 percent of the fish survived from Bennett Dam to Portland. Standardized estimates showed that survival rates in the Minto Dam to Bennett Dam reach were higher (0.634 per $100 \mathrm{rkm}$ ) than in the Bennett Dam to Portland reach (0.534 per $100 \mathrm{rkm})$. Cumulative survival from the MTR to Portland was 24 percent, which is lower than previously observed. Beeman and others (2015) found that survival of juvenile Chinook salmon and steelhead ranged from 39 to 65 percent in this reach during 2013 and 2014. The discrepancy in survival rates between tagged fish in our study and tagged fish from previous studies provides additional evidence to support earlier observations that factors such as release timing or fish source may have influenced observations in this study.

Collectively, the inclusion of PIT tags in study fish, and laboratory studies that addressed tag failure and tag loss, allowed us to account for potential bias in survival estimates. Acoustic transmitters have a finite operating life and we expected to observe downstream movements by acoustic+PIT-tagged fish beyond the period in which acoustic transmitters operated during our study. Because tagging occurred in early August 2014 we expected acoustic transmitters to expire by early November 2014. Previous ODFW studies have shown that some juvenile Chinook salmon overwinter in the Willamette River Basin and outmigrate the following spring or summer (T.A. Friesen and M.A. Johnson, ODFW, written commun., February 2013). Given these data, we expected to detect acoustic+PIT-tagged fish on PIT-tag antennas at Willamette Falls for several months after their acoustic transmitters stopped functioning. Most fish migrated downstream shortly after release, but some passage occurred at Willamette Falls through June 2015 (table 6). These data allowed us to account for protracted residence times in the Willamette River Basin. Similarly, the tag-loss study allowed us to account for bias related to that factor. Comparison of unadjusted and adjusted survival estimates showed that tag failure and tag loss negatively biased survival estimates by about 5 percent. 


\section{Acknowledgments}

This study was completed with the assistance of many people and organizations. The Oregon Department of Fish and Wildlife and staff at the Marion Forks Hatchery provided space, facilities for holding and tagging, and study fish. U.S. Army Corps of Engineers staff at Detroit and Big Cliff Dams provided assistance with access at the sites to install, operate, and maintain equipment used to monitor tagged fish near the dams. Staff from the Stayton Public Works Department provided access to the Stayton Canal. Robert Wertheimer and Scott Fielding provided invaluable assistance with developing the study plan, securing the funding, and assisting with several aspects of the study design, implementation, analysis, and reporting process. Mary Karen Scullion and Chris Walker provided updates on dam operating scenarios at Detroit Dam that were important for study planning. Our administrative and scientific colleagues at the Columbia River Research Laboratory contributed greatly to this study. In particular, we thank Lisa Gee, Kyle Martens, Russell Perry, John Plumb, Collin Smith, Ryan Tomka, and Andrew Wells for their efforts. We thank Nick Ackerman and John Plumb for reviewing this document and providing editorial comments that improved the quality of the document. This study was funded by the U.S. Army Corps of Engineers under contract W66QKZ31580064.

\section{References Cited}

Allison, P.D., 1995, Survival analysis using SAS - A practical guide: Cary, North Carolina, SAS Institute, Inc., 292 p.

Axel, G., Beeman, J., Brown, R., Eppard, B., Fielding, S., Hockersmith, E., Liedtke, T., Peery, C., and Woodley, C., 2011, Surgical protocols for implanting JSATS transmitters into juvenile salmonids for studies conducted for the U.S. Army Corps of Engineers: Surgical Protocols Steering Committee, Prepared for the U.S. Army Corps of Engineers, Portland, Oregon.

Beeman, J.W., and Adams, N.S., eds., 2015, In-reservoir behavior, dam passage, and downstream migration of juvenile Chinook salmon and juvenile steelhead from Detroit Reservoir and Dam to Portland, Oregon, February 2013-February 2014: U.S. Geological Survey Open-File Report 20151090, 92 p., accessed July 2015 , at http://dx.doi.org/10.3133/ofr20151090.

Beeman, J.W., Hansel, H.C., Hansen, A.C., Evans, S.D., Haner, P.V., Hatton, T.W., Kofoot, E.E., Sprando, J.M., and Smith, C.D., 2014, Behavior and dam passage of juvenile Chinook salmon and juvenile steelhead at Detroit Reservoir and Dam, Oregon, March 2012-February 2013: U.S. Geological Survey Open-File Report 2014-1144, 62 p., accessed June 2015 , at http://dx.doi.org/10.3133/ofr20141144.

Beeman, J.W., and Perry, R.W., 2012, Bias from false-positive detections and their removal in studies using telemetry, in Adams, N.S., Beeman, J.W., and Eiler, J.H., eds., Telemetry techniques-A user guide for fisheries research: Bethesda, Maryland, American Fisheries Society, p. 505-518.

Burnham, K.P., Anderson, D.R., White, G.C., Brownie, C., and Pollock, K.H., 1987, Design and analysis methods for fish survival experiments based on release-recapture: Bethesda, Maryland, American Fisheries Society Monograph 5, 737 p.

Cormack, R.M., 1964, Estimates of survival from the sighting of marked animals: Biometrika, v. 51, nos. 3-4, p. 429-438.

Jolly, G.M., 1965, Explicit estimates from capture-recapture data with both death and immigrationstochastic model: Biometrika, v. 52, nos. 1-2, p. 225-247.

Karchesky, C.M., Pyper, B.J., Hanks, M.E., and Cramer, D.P., 2010, Final report: evaluation of spring Chinook salmon downstream migration at the Willamette Falls Project, spring 2010. Prepared for Portland General Electric, Portland, Oregon. 
Kock, T.J., Liedtke, T.L., Ekstrom, B.K., and Hurst, W.R., 2015, Evaluation of two juvenile salmon collection devices at Cowlitz Falls Dam, Washington, 2014: U.S. Geological Survey Open-File Report 2015-1054, 30 p.

Lady, J.M., Westhagen, P., and Skalski, J.R., 2008, USER 4-User specified estimation routine: Seattle, University of Washington, School of Aquatic and Fishery Sciences, accessed July 2015, at www.cbr.washington.edu/analysis/apps/user.

McMichael, G.A., Eppard, M.B., Carlson, T.J., Carter, J.A., Ebberts, B.D., Brown, R.S., Weiland, M., Ploskey, G.R., Harnish, R.A., and Deng, Z.D., 2010, The juvenile salmon acoustic telemetry systemA new tool: Fisheries, v. 35, no.1, p. 9-22.

National Oceanic and Atmospheric Administration, 2008, Endangered Species Act Section 7(a)(2) Consultation Biological Opinion \& Magnuson-Stevens Fishery Conservation \& Management Act Essential Fish Habitat Consultation: National Oceanic and Atmospheric Administration, Fisheries Log Number FINWR12000/02117.

Normandeau Associates, Inc., 2010, Estimates of direct survival and injury of rainbow trout (Oncorhynchus mykiss) passing spillway, turbine, and regulating outlet at Detroit Dam, Oregon: Normandeau Associates, Inc., prepared for U.S. Army Corps of Engineers, Portland, Oregon, contract W912EF-08-D-0005.

Perry, R.W., Plumb, J.M., Fielding, S.D., Adams, N.S., and Rondorf, D.W., 2014, Comparing effects of transmitters within and among populations-Applications to swimming performance of juvenile Chinook salmon: Transactions of the American Fisheries Society, v. 142, p. 901-911.

Perry, R.W., Castro-Santos, T., Holbrook, C.M., and Sandford, B.P., 2012, Using mark-recapture models to estimate survival from telemetry data, in Adams, N.S., Beeman, J.W., and Eiler, J., eds., Telemetry techniques - A user guide for fisheries research: Bethesda, Maryland, American Fisheries Society, p. 453-476.

Seber, G.A.F., 1965, A note on the multiple-recapture census: Biometrika, v. 52, nos. 1-2, p. $249-259$.

Skalski, J.R., Lady, J., Townsend, R., Giorgi, A.E., Stevenson, J.R., Peven, C.M, and McDonald, R.D., 2001, Estimating in-river survival of migrating salmonid smolts using radiotelemetry: Canadian Journal of Fisheries and Aquatic Sciences, v. 58, p. 1987-1997.

Street, L.E., and Faber, D.M., 2015, Willamette project juvenile salmonid PIT interrogation system development-North Santiam River near Bennett Dams: Oregon Department of Fish and Wildlife, report prepared for the U.S. Army Corps of Engineers, Portland, Oregon, Project Number W9127N10-2-0008.

Tiffan, K.F., and Connor, W.P., 2003, Effects of summer flow augmentation on the migratory behavior and survival of juvenile Snake River fall Chinook salmon: U.S. Geological Survey and the U.S. Fish and Wildlife Service, prepared for the Bonneville Power Administration, Portland, Oregon, Project Number 1991-02900.

Tiffan, K.F., and Connor, W.P., 2004, Effects of summer flow augmentation on the migratory behavior and survival of juvenile Snake River fall Chinook salmon: U.S. Geological Survey and the U.S. Fish and Wildlife Service, prepared for the Bonneville Power Administration, Portland, Oregon, Project Number 1991-02900. 
Titzler, P.S., McMichael, G.A., and Carter, J.A., 2010, Autonomous acoustic receiver deployment and mooring techniques for use in large rivers and estuaries: North American Journal of Fisheries Management, v. 30, p. 853-859.

Townsend, R.L., Skalski, J.R., Dillingham, P., and Steig, T.W., 2006, Correcting bias in survival estimation resulting from tag failure in acoustic and radiotelemetry studies: Journal of Agricultural, Biological, and Environmental Statistics, v. 11, p. 183-196.

Weiland, M.A., Ploskey, G.R., Hughes, J.S., Deng, Z., Fu, T., Monter, T.J., Johnson, G.E., Khan, F., Wilberding, M.C., Cushing, A.W., Zimmerman, S.A., Faber, D.M., Durham, R.E., Townsend, R.L., Skalski, J.R., Kim, J., Fischer, E.S., and Meyer, M.M., 2009, Acoustic telemetry evaluation of juvenile salmonid passage and survival at John Day Dam with emphasis on the prototype surface flow outlet, 2008: Richland, Washington, Pacific Northwest National Laboratory, Report PNNL-18890, $259 \mathrm{p}$. 
Publishing support provided by the U.S. Geological Survey

Science Publishing Network, Tacoma Publishing Service Center

For more information concerning the research in this report, contact the Director, Western Fisheries Research Center U.S. Geological Survey

6505 NE 65th Street

Seattle, Washington 98115

http://wfrc.usgs.gov/ 
